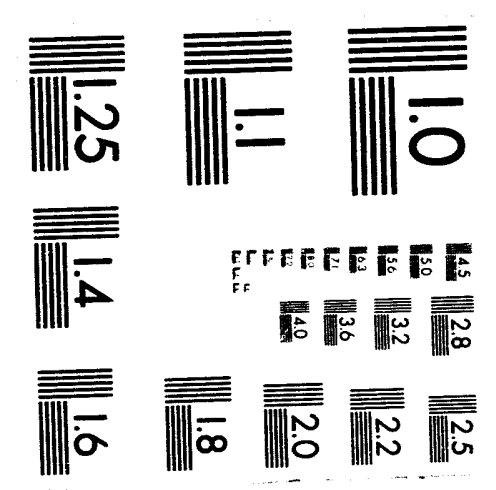



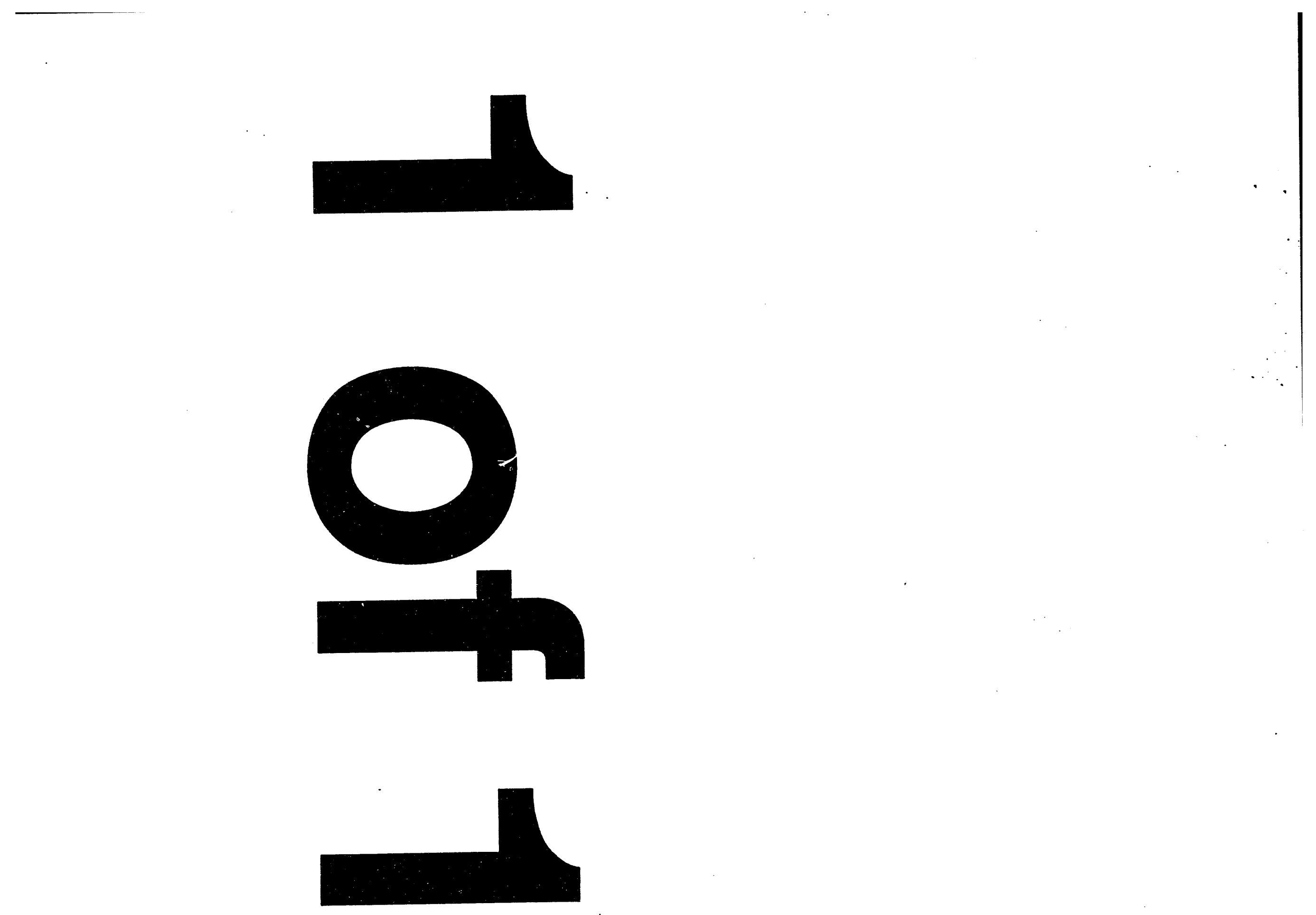
Energy Systems Environmental Restoration Program ORNL Environmental Restoration Program

\title{
Health and Safety Work Plan for Sampling Colloids in Waste Area Grouping 5 at Oak Ridge National Laboratory, Oak Ridge, Tennessee
}

\author{
J. D. Marsh \\ J. F. McCarthy
}

Date Issued-January 1994

\author{
Prepared by \\ Environmental Sciences Division \\ Oak Ridge National Laboratory \\ Prepared for \\ U.S. Department of Energy
}

Office of Environmental Restoration and Waste Management under budget and reporting code EW 20

OAK RIDGE NATIONAL LABORATORY

Oak Ridge, Tennessee 37831-6285

managed by

MARTIN MARIETTA ENERGY SYSTEMS, INC.

for the

U.S. DEPARTMENT OF ENERGY

under contract DE-AC05-84OR21400 


\section{Author Affiliations}

J. D. Marsh and J. F. McCarthy are members of the Environmental Sciences Division at Oak Ridge National Laboratory, Martin Marietta Energy Systems, Inc. 
Prepared by: John F. McCarthy and J. Daniel Marsh

Purpose: The objective will be to sample groundwater for colloids and determine the role of colloids and natural organic matter on the migration of radionuclides at WAG 5.

Reviewed/Approved by:

Office of Radiation Protection Representative:

Industrial Hygiene Section Representative:

Mitch Conner

E. R. Barham

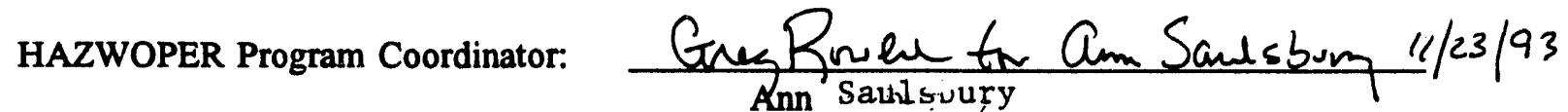

Industrial Safety Representative:

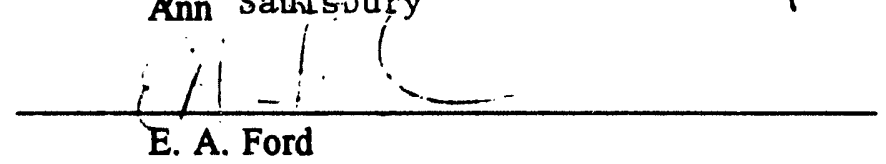

Emergency Response Representative:

ERP ES\&H Coordinator:

ORNL WAG-5 ERP Manager:

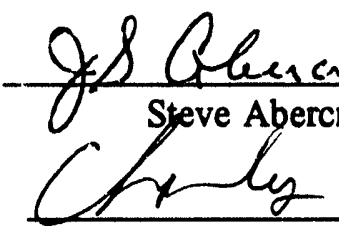

Charles Clark

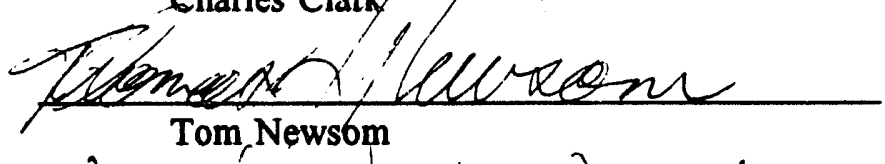

Site Safety and Health Officer:

DOE ORNL Program Manager
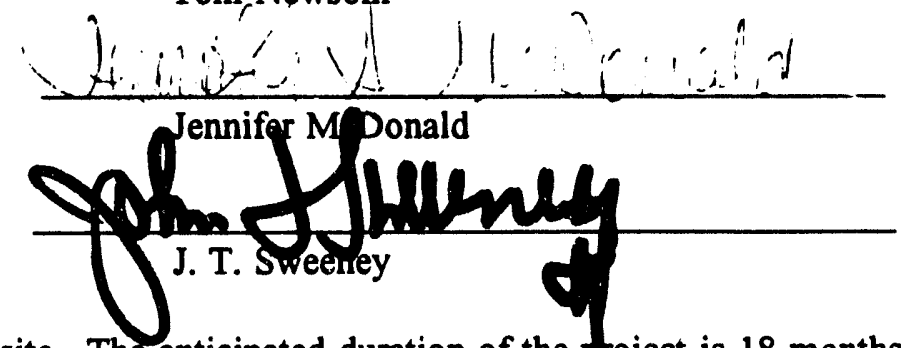

This plan will be kept at the project site. The anticipated duration of the project is 18 months. 


\section{CONTENTS}

ABBREVIATIONS $\ldots \ldots \ldots \ldots \ldots \ldots \ldots \ldots \ldots \ldots \ldots \ldots \ldots \ldots \ldots \ldots$

EXECUTIVE SUMMARY $\ldots \ldots \ldots \ldots \ldots \ldots \ldots \ldots \ldots \ldots \ldots \ldots$

1. INTRODUCTION $\ldots \ldots \ldots \ldots \ldots \ldots \ldots \ldots \ldots \ldots \ldots \ldots \ldots$

1.1 PROJECT AND SITE DESCRIPTION $\ldots \ldots \ldots \ldots \ldots \ldots \ldots \ldots$

2. SITE ORGANIZATION AND COORDINATION $\ldots \ldots \ldots \ldots \ldots \ldots \ldots \ldots$

2.1 PROJECT MANAGER $\ldots \ldots \ldots \ldots \ldots \ldots \ldots \ldots \ldots \ldots \ldots \ldots \ldots \ldots$

2.2 SAMPLING TEAM LEADER $\ldots \ldots \ldots \ldots \ldots \ldots \ldots \ldots \ldots \ldots \ldots$

2.3 SITE SAFETY AND HEALTH OFFICER $\ldots \ldots \ldots \ldots \ldots \ldots \ldots \ldots \ldots . \ldots$

2.4 FIELD PERSONNEL $\ldots \ldots \ldots \ldots \ldots \ldots \ldots \ldots \ldots \ldots \ldots \ldots \ldots$

2.5 RADIATION PROTECTION $\ldots \ldots \ldots \ldots \ldots \ldots \ldots \ldots \ldots \ldots \ldots \ldots$

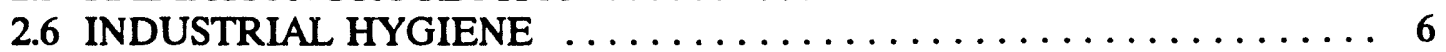

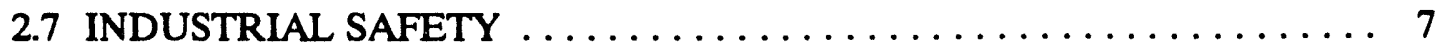

3. PROJECT HAZARD EVALUATION $\ldots \ldots \ldots \ldots \ldots \ldots \ldots \ldots \ldots \ldots \ldots$

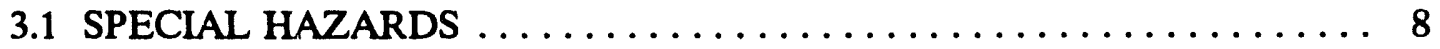

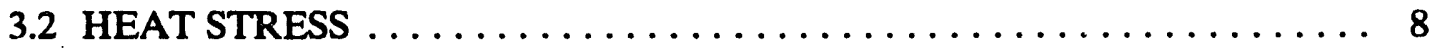

3.3 COLD STRESS $\ldots \ldots \ldots \ldots \ldots \ldots \ldots \ldots \ldots \ldots \ldots \ldots \ldots \ldots \ldots \ldots \ldots \ldots$

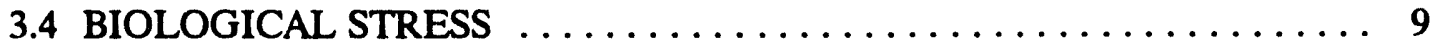

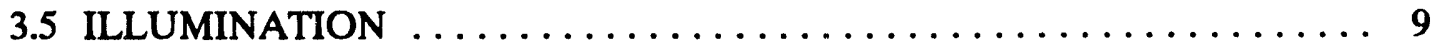

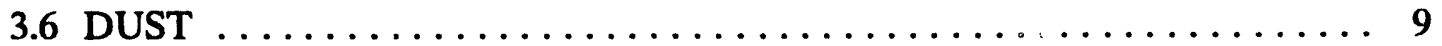

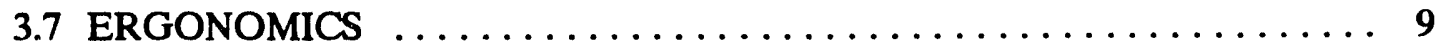

3.8 TRIPPING AND FALLING $\ldots \ldots \ldots \ldots \ldots \ldots \ldots \ldots \ldots \ldots \ldots$

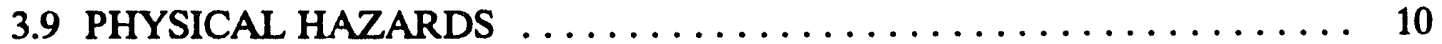

3.10 CONSTRUCTION HAZARDS $\ldots \ldots \ldots \ldots \ldots \ldots \ldots \ldots \ldots \ldots \ldots \ldots$

3.11 CHEMICAL HAZARDS $\ldots \ldots \ldots \ldots \ldots \ldots \ldots \ldots \ldots \ldots \ldots \ldots \ldots \ldots \ldots$

3.12 IONIZING RADIOLOGICAL HAZARDS $\ldots \ldots \ldots \ldots \ldots \ldots \ldots \ldots, 10$

3.13 NONIONIZING RADIOLOGICAL HAZARDS $\ldots \ldots \ldots \ldots \ldots \ldots \ldots . \ldots$

3.14 BIOLOGICALNECTOR HAZARDS $\ldots \ldots \ldots \ldots \ldots \ldots \ldots \ldots \ldots$

3.15 DESCRIPTION OF HAZARDS AND CONTROLS ........... 11

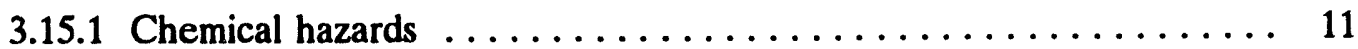

3.15 .2 Fire/Explosion . . . . . . . . . . . . . . . . . . . 11

3.15.3 Confined/Enclosed Spaces (Not Applicable) . . . . . . . . . . 11

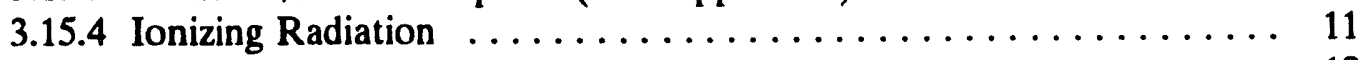

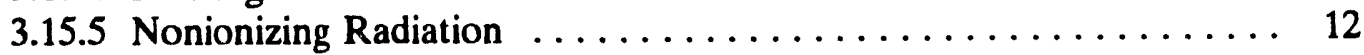

3.15 .6 Electrical Hazards . . . . . . . . . . . . . . . . . 13

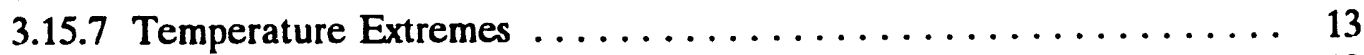

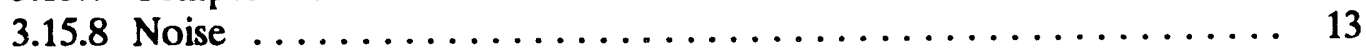

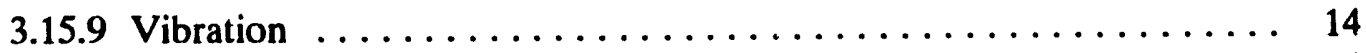

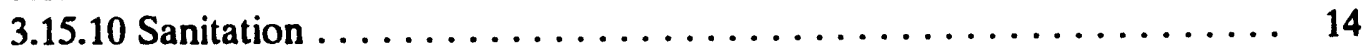

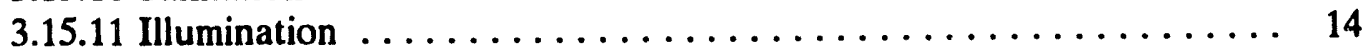

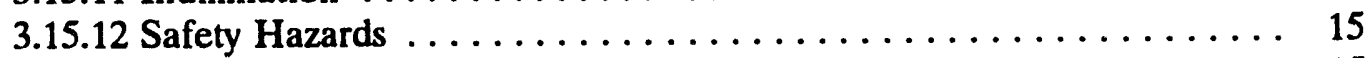

3.15 .13 Biological Hazards $\ldots \ldots \ldots \ldots \ldots \ldots \ldots \ldots \ldots \ldots \ldots \ldots \ldots \ldots$ 


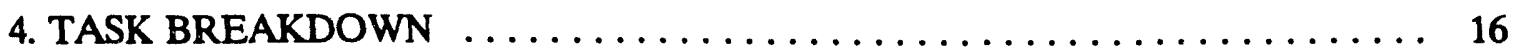

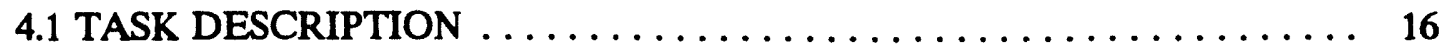

5. MONITORING REQUIREMENTS $\ldots \ldots \ldots \ldots \ldots \ldots \ldots \ldots \ldots \ldots \ldots, 18$

5.1 DIRECT READING INSTRUMENTS $\ldots \ldots \ldots \ldots \ldots \ldots \ldots \ldots \ldots, 18$

5.2 PERSONAL MONITORING $\ldots \ldots \ldots \ldots \ldots \ldots \ldots \ldots \ldots \ldots \ldots, 18$

6. DECONTAMINATION $\ldots \ldots \ldots \ldots \ldots \ldots \ldots \ldots \ldots \ldots \ldots \ldots \ldots, 20$

7. EMERGENCY PREPAREDNESS $\ldots \ldots \ldots \ldots \ldots \ldots \ldots \ldots \ldots \ldots \ldots \ldots \ldots \ldots \ldots$

8. TRAINING REQUIREMENTS $\ldots \ldots \ldots \ldots \ldots \ldots \ldots \ldots \ldots \ldots \ldots \ldots, 22$

APPENDIX A: WAG 5 Existing Data $\ldots \ldots \ldots \ldots \ldots \ldots \ldots \ldots \ldots \ldots \ldots$ A-1

APPENDIX B: List of Tasks, Hazards, and Controls ............... B-1

APPENDIX C: Material Safety Data Sheets $\ldots \ldots \ldots \ldots \ldots \ldots \ldots \ldots \ldots \ldots \ldots \ldots \ldots \ldots$ 


\section{ABBREVIATIONS}

ACGIH

DOE

ESD

HAZWOPER

HP

HPC

IH

IS

LSS

MSDS

OHF

ORNL

P?

PPE

QA

RI/FS

RP

RWP

SI

SSHO

SSHP

STL

SWSA

WAG

WBGT
American Conference of Governmental Industrial Hygienists

U. S. Department of Energy

Environmental Sciences Division

Hazardous Waste Operations and Emergency Response

Health Physics Section

HAZWOPER Program Coordinator

Industrial Hygiene Section

Industrial Safety Section

Laboratory Shift Supervisor

material safety data sheet

Old Hydrofracture Facility

Oak Ridge National Laboratory

Project Manager

personal protective equipment

quality assurance

remedial investigation/feasibility study

Radiation Protection Surveillance Section

radiation work permit

site investigation

site safety and health officer

site safety and health plan

Sampling Team Leader

solid waste storage area

waste area grouping

wet bulb globe temperature 


\section{EXECUTIVE SUMMARY}

This Work Plan/Site Safety and Health Plan (SSHP) and the attached work plan are for the performance of the colloid sampling project at WAG 5. The work will be conducted by the Oak Ridge National Laboratory (ORNL) Environmental Sciences Division (ESD) and associated ORNL environmental, safety, and health support groups. This activity will fall under the scope of 29 CFR 1910.120, Hazardous Waste Operations and Emergency Response (HAZWOPER). The purpose of this document is to establish health and safety guidelines to be followed by all personnel involved in conducting work for this project. Work will be conducted in accordance with requirements as stipulated in the ORNL HAZWOPER Program Manual, and applicable ORNL, Martin Marietta Energy Systems, Inc., and U. S. Department of Energy (DOE) policies and procedures. 


\section{INTRODUCTION}

This Work Plan/Site Safety and Health Plan (SSHP) and the attached work plan are for the performance of the colloid sampling project at WAG 5. The work will be conducted by the Oak Ridge National Laboratory (ORNL) Environmental Sciences Division (ESD) and associated ORNL environmental, safety, and health support groups. This activity will fall under the scope of 29 CFR 1910.120, Hazardous Waste Operations and Emergency Response (HAZWOPER). The purpose of this document is to establish health and safety guidelines to be followed by all personnel involved in conducting work for this project. Work will be conducted in accordance with requirements as stipulated in the ORNL HAZWOPER Program Manual, and applicable ORNL, Martin Marietta Energy Systems, Inc., and U. S. Department of Energy (DOE) policies and procedures.

The levels of protection and the procedures specified in this plan are based on the best information available from historical data and preliminary evaluations of the area. Therefore, these recommendations represent the minimum health and safety requirements to be observed by all personnel engaged in this project. Unforeseeable site conditions or changes in scope of work may warrant a reassessment of protection levels and controls stated. All adjustments to the plan must have prior approval by the safety and health disciplines signing the original plan.

\subsection{PROJECT AND SITE DESCRIPTION}

The project is located at the WAG 5. WAG 5 is in Melton Valley, south of the main ORNL plant area. Previous sampling results suggest that the primary contaminants of concern will be radiological $\left({ }^{90} \mathrm{Sr},{ }^{3} \mathrm{H}\right.$, and alpha emitting radioisotopes). The gross beta, which includes ${ }^{90} \mathrm{Sr}$, ranges from background to $110,000 \mathrm{pCi} / \mathrm{L}$, gross alpha from background to $4,000 \mathrm{pCi} / \mathrm{L}$, and tritium from bacl:ground to $600,000,000 \mathrm{pCi} / \mathrm{L}$. Tritium will be in the form of tritiated water. A site map and a radiological walkover survey are included in Appendix A. The radiological walkover survey indicates the external exposure around WAG 5. The site map shows the locations of the wells and seeps. However, it should be noted that the activities of this project will not include sampling at the Old Hydrofracture Facility (OHF), the OHF pond, the process waste sludge basin, or in any building or tank. There have been no hazardous volatile chemicals or radioactive gases detected while opening wells for routine monitoring at well sites or at seeps. External and internal exposure to radioactive material will be controlled primarily by administrative controls and personal protective er,uipment as described below.

The work conducted in this task will be limited to sampling of groundwater and possibly surface water exiting seeps. The goal of the work is to determine if radionuclides in groundwater or exiting seeps are adsorbed to colloidal (submicron-sized) particles or complexed with natural organic matter in the groundwater. Groundwater containing actinides

will be sampled and filtered at the well-head. Filters will range from $0.45 \mu \mathrm{m}(450 \mathrm{~nm})$ to $1 \mathrm{~nm}$ ( 3000 dalton molecular weight) in nominal size cut-off. Groundwater will be filtered online (before exiting the sample tube) to avoid introduction of artifacts that could produce colloids during sampling. Slow fluid pumping rates will be used to minimize shear forces around the well that could entrain colloids that are normally immobile. Prior to sampling, the chemical and thermodynamic conditions $(\mathrm{pH}$, electrode potential, specific conductance, 
dissolved oxygen, alkalinity, temperature) of the groundwater will be measured using in-line flow cells. Purged water will be collected and contained in carboys or barrels for appropriate disposal.

The primary emphasis of this work will be on wells that have elevated levels of actinides, since these radioisotopes are expected to have the greatest affinity for adsorbing to groundwater colloids. Part of this work will involve repeated monitoring at some wells since storm events are expected to mobilize colloid-associated contaminants. However, the location of the wells we will sample is subject to change, depending on results of compliance monitoring.

The work will be limited to collection and filtration of water samples. There will be no excavation, nor will there be any collection of sediments or soil. Prior to sampling of a new well or seep, $\mathrm{HP} / \mathrm{HH}$ will survey the work area to identify any radiological or contamination hazards and set requirements for zoning and PPE. Already existing wells will be evaluated by previous sampling data. A thin window beta-gamma "pancake" meter will be used to detect low energy beta activity. Groundwater samples will be monitored by HP or, with HP's permission, by the SSHO at the site to determine that the samples do not exceed the action guidelines of $>100 \mathrm{cpm}$ above background, based on survey meters; if that guideline is exceeded, HP will be notified immediately for guidance and additional instructions. All personnel will perform a whole body frisk with a hand-held monitor (alpha and beta/gamma) before leaving the sampling site; in addition, personnel will be frisked with the half-body monitor in Building 7831 as a secondary precaution prior to exiting WAG 5. 


\section{SITE ORGANIZATION AND COORDINATION}

The work will be performed by ESD of ORNL. ORNL Industrial Hygiene, Industrial Safety, and Radiation Protection will appropriate monitoring and oversight. Prior to the initial sampling of groundwater at any location, the site will be evaluated by HP for radiological hazard and by IH for health hazards. Specifically, HP/IH will be present to monitor for site hazards the first time any new sampling well is opened, and will make recommendations for any protective requirements or any additional monitoring that will be required for present or future sampling of that well. IH and RP will decide if monitoring and oversight of sampling activities at any sampling site can be conducted by the SSHO or if the presence of an $\mathrm{YH}$ or $\mathrm{RP}$ technician is necessary during sampling.

The following section details the organizational structure for this project. Key personnel and their project responsibilities follow. Team members from ESD include J. F. McCarthy, J. D. Marsh, J. McDonald, T. Thomas, T. Knowles, B. Gu, and W. L. Webster. J. McDonald will serve as the Site Team Leader (STL) and SSHO, and J. D. Marsh will serve as back-up STL and SSHO. General responsibilities of all project staff include

- safeguarding record materials including, but not limited to, field note books, raw data sheets, and chain of custody forms;

- maintaining complete, factual, detailed, and objective program notes;

- retaining records of all analyses and procedures used for the WAG $2 \mathrm{RI} / \mathrm{FS}$ and SI projects;

- ensuring that proper waste management procedures are followed; and

- ensuring that the requirements of the Sampling and Analysis Plan, QA Plan, Data Management Plan, and the Health and Safety Plan are satisfied.

\section{PROJECT MANAGER}

The PM oversees all efforts of the project and provides guidance to project personnel. Responsibilities of the PM include

- managing the project and overseeing the technical and programmatic activities of the health and safety program,

- assigning sufficient resources to maintain and implement the health and safety program, and

- ensuring that adequate health and safety systems (i.e., policies, plans, procedures, materials) are in place and operational. 


\section{SAMPLING TEAM LEADER}

The STL is responsible for oversight of the sampling activities for the project. He/she will be responsible foi site accessibility, safety, QA, and waste management and may delegate further responsibilities to other team members. Specific responsibilities of the STL are listed below:

1. coordinates site operations, including logistics;

2. interfaces with plant and project personnel;

3. notifies appropriate personnel of work schedules;

4. maintains and controls all site records;

5. determines in-field procedural variances in response to site conditions;

6. documents and reports unforeseen site changes and corrective actions; and

7. coordinates waste disposal following procedures established by the ORNL-ER-P Waste Management Plan guidance document.

\section{SITE SAFETY AND HEALTH OFFICER}

The project will designate a qualified site-specific SSHO, who must be approved by the HAZWOPER Program Coordinator as well as the alternates, who will implement, monitor, and enforce the site specific Health and Safety plan. The SSHO is the primary on-site contact for safety and health during field activities. They oversee the on-site execution of all field activities regarding safety and health procedures and has the authority to stop all work if conditions are judged to be hazardous to on-site personnel or to the public. The SSHO will remain on-site at all times while workers are performing site activities. Other specific responsibilities follow.

1. Prior to initiation of site activities, a pre-entry briefing will be conducted to ensure that personnel receive a copy of the site specific health and safety plan and are aware of its provisions; are instructed on how the work will be accomplished and how to ensure workers' safety; are familiar with potential hazards, routes of entry, and health effects that could be hazardous during this project; and are familiar with planned emergency procedures;

2. The SSHO Ensures that employees meet the required level of training, medical requirements including respirator fit test (as needed), attend a pre-entry briefing on project and potential site hazards, and review the Work Plan and SSHP. Maintains copies of documentation of the above at the project site and ensures documentation is available for on-site review. Note: the ORNL Special Access Training Badge will be used as verification of training. See Section 8 for site entry requirements

3. Require personnel to obtain immediate medical attention in the case of a work-related injury or illness. 
4. Deny access to all or any portion of the work area as warranted.

5. Order work to cease, evacuation of the work area by all personnel, and reestablish safe working conditions, as needed.

6. Control access to the site by visitors and unauthorized personnel. Advise visitors and unauthorized personnel of their responsibilities, and ensure they meet access requirements, before entry is allowed.

7. Ensure the correct field execution of the Work Plan and SSHP.

8. Ensure this Work Plan and SSHP are revised and approved if there are changes.

9. Advise emergency response personnel in an emergency.

10. Coordinate with Industrial Hygiene (IH), Industrial Safety (IS), and Radiation Protection (RP) to establish site work zones and to recommend additional requirements for personnel protection, monitoring, and other controls.

11. Coordinate and minimize the number of personnel and amount of equipment in the work zones.

12. Coordinate accident prevention by oversight of field activities and being aware of all site operations.

13. Ensure that needed work permits (e.g., radiation work permits) are obtained and made available on site.

14. Ensure that IH, IS, and RP are contacted prior to commencement of site work to (1) notify of intent to begin work and (2) request monitoring support, as recommended by IH, IS, or RP during their initial survey of each sampling site.

15. Conduct daily inspection of the work site (See site surveillance check-list, Appendix B).

16. Provide the HAZWOPER Program Coordinator (HPC) a list of personnel participating in site activities to determine the need for inclusion in the hazardous waste worker medical surveillance program.

\section{FIELD PERSONNEL}

1. Taking all reasonable precautions to prevent injury to themselves and to their fellow employees; being alert to potentially harmful situations.

2. Performing only those tasks that they believe they can do safely and immediately reporting any accidents and/or unsafe conditions to the SSHO.

3. Notifying the SSHO of any special medical conditions (i.e., allergies, contact lenses, diabetes and medication use). Although highly recommended, it is not mandatory to report pregnancies, per Energy Systems policy under the Reproductive Hazards Program. 
4. Preventing spillage to the extent possible. If a spill occurs, contain the spill, notify the SSHO, and clean up immediately using safe cleanup measures as directed by the SSHO. Note: Do not engage in spill containment or cleanup if conditions are not safe and if the cleanup cannot be accomplished with supplies available at the site. Evacuate the area. All spills must be reported to the ORNL Environmental Interface (4-8770).

5. Avoid splashing materials to the extent possible.

6. Practice good housekeeping by keeping the work area neat, clean, and orderly to the extent possible.

7. Reporting all injuries, no matter how minor.

\section{RADIATION PROTECTION}

ORNL Radiation Protection will be responsible for oversight and approval of personnel protection requirements related to radiation protection. Mitch Conner, Office of Radiation Protection, will review and approve the Work Plan and SSHP prior to commencement of field activities. The Office of Radiation Protection representative will authorize a return to work after any on-site hazard has been resolved related to radiation protection. ORNL Radiation Protection will be consulted prior to entry into any posted Radiological Area and will instruct field participants on requirements for that area, including the need for a Radiation Work Permit, appropriate monitoring, dosimetry, and personal protective equipment.

\section{INDUSTRIAL HYGIENE}

The ORNL Industrial Hygiene Section and the HAZWOPER Program Coordinator (HPC) will be responsible for the oversight and approval of personnel protection related to industrial hygiene and the requirements of 29 CFR 1910.120. Ray Barham, the IH Divisional Representative for the Environmental Sciences Division, and Ann Saulsbury, the HAZWOPER Program Coordinator will approve the Work Plan and SSHP prior to commencement of field activities. A representative from the Industrial Hygiene Section will accompany the group during the initial activities to determine potential IH hazards. In addition, the IH representative will have stop-work authority and will provide guidance regarding personal protective equipment, and industrial hygiene monitoring and sampling requirements.

The SSHO will provide the HPC a list of ORNL individuals who may be participating in site activities. Based on program requirements, work history, and potential for exposure of the worker, the HPC will determine which individuals must be placed on the hazardous waste worker medical surveillance program. The HPC will then provide the ORNL medical facility with a list of individuals who are to be included in the hazardous waste worker medical surveillance program. 


\section{INDUSTRIAL SAFETY}

The ORNL Industrial Safety Section will be responsible for oversight and approval of personnel protection related to safety. Industrial Safety will review and approve the Work Plan and SSHP prior to commencement of field activities. Industrial Safety will have stopwork authority and will provide guidance regarding potential safety hazards, personal protective equipment and safety requirements. 


\section{PROJECT HAZARD EVALUATION}

\subsection{SPECIAL HAZARDS}

In addition to the expected hazards associated with sites other potentially harmful hazards must be identified. Examples of some of these hazards are; physical, chemical, radiological, underground and overhead hazards as well as heat or cold stress, noise, illumination, ergonomics, and biological factors. below.

All site investigative and excavative personnel may be exposed to the hazardous outlined

\subsection{HEAT STRESS}

Activities being conducted at sites may be physically demanding during some of the site activities, possibly compounded through the use of protective clothing and equipment, moderate to heavy work loads, ambient air temperatures, relative humidity, and exposure to nonionizing radiation.

Two important factors will help personnel function in hot environments: acclimatization and consumption of fluids. Acclimation is a physical and psychological adjustment that workers experience during the first one or two weeks of work in hot environmental conditions. Especially during this period, workers should concentrate on maintaining a balanced diet, consuming plenty of fluids throughout the day, and remaining aware of telltale signs of heat-related stress, such as headaches, dizziness, high body temperature, and increased heart rate. It is imperative that the SSHO be informed of these conditions if a worker experiences these signs.

All activities that take place at the sites require the use of a "buddy" system. As field activities continue, all personnel should be aware of their buddy's condition and of signs of heat-related stress. The SSHO will institute a work and rest regimen when conditions become difficult to combat heat-related disorders, according to his or her best professional judgement and guidelines published by the American Conference of Governmental Industrial Hygienists (ACGIH) ${ }^{2}$.

\subsection{COLD STRESS}

Activities being conducted at site may be physically demanding during winter months compounded through the use of protective clothing and equipment, moderate to heave work loads, ambient air temperatures, relative humidity, wet or rainy conditions, wind speed, and exposure to nonionizing radiation.

Two important factors will help personnel function in cold environments: acclimatization and proper clothing. Acclimatization is a physical and psychological adjustment that workers experience during the first one or two weeks of work in cold environmental conditions. Especially during this period, workers should concentrate on maintaining a balanced diet, consuming plenty of fluids throughout the day, and remaining aware of telltale signs of cold- 
related stress, such as headaches, numbness in digits or extremities, dizziness, low body temperature, and decreased heart rate. It is imperative that the SSHO be informed of this condition if a worker experiences these symptoms.

All activities that take place at the sites require the use of a buddy system. As field activities continue, all personnel should be aware of their buddy's condition and of signs of cold-related stress. The SSHO will institute a work and rest regimen to combat cold-related disorders, according to his or her best professional judgement and guidelines published by the American Conference of Governmental Industrial Hygienist, ${ }^{2}$ when those conditions arise

\subsection{BIOLOGICAL STRESS}

Field conditions may present a variety of biological stresses, and it is the responsibility of personnel to inform the SSHO of health conditions they have that may be affected by site conditions. Examples of these stresses may be, but are not limited to, insect bites, or stings, ticks, poison ivy, pollens and grasses, snakes, etc.

\subsection{ILLUMINATION}

Activities at any sites normally will be conducted during daylight hours. A conservative guideline may be that work will commence 15 minutes after sunrise and conclude 15 minutes prior to sunset.

\subsection{DUST}

The generation of respirable dust shall be kept to a minimal amount. A rule of thumb is that a visible cloud of dust will constitute an action limit. An engineering control may be employed, such as wetting the area with deionized or potable water, sprayed as a fine mist from a garden sprayer. In the unlikely event that engineering controls are unsuccessful, the IH department will be summoned to assess the situation and provide guidance.

\subsection{ERGONOMICS}

The interaction of personnel with the working environment may also present potential hazards at this site, such as incorrectly lifting heavy loads, equipment vibrations, improper body positioning, and negotiating physical obstacles when traversing ditches and brush. Personnel should always position themselves properly and lift from the legs when lifting equipment or heavy objectr: and should rely on the buddy system to assist in lifting loads greater than 50 pounds. Back strain, the mast common engonomic hazand in the field, may be easily avoided, provided that the site workers ask for assistance when they need it.

\subsection{TRIPPING AND FALLING}

Tripping and falling hazards will be present in all areas having uneven surface and wet grass. Rubber boots will be worn to improve traction on wet surfaces. Personnel will be 
warned of those hazards and proper PPE requirements during daily briefings. Specific Hazards and controls are described below. An X in each $\square$ indicates existing conditions or those that may be a result of site operations.

Task: Sampling Groundwater

\subsection{PHYSICAL HAZARDS}

X Heat Stress

Confined Space

$\mathrm{X}$ Tripping/Falling

Oxygen Deficient
X Cold Stress

Enclosed Space

High Voltage

$\mathrm{X}$ Explosive/Flammable
Noise

Heavy Lifting

High Pressure Water

Vibration

\subsection{CONSTRUCTION HAZARDS}
$\square \quad$ Trenching
$\square$ Demolition
$\square \quad$ Ladders

$\square \quad$ Excavating

$\square$ High Work

\subsection{CHEMICAL HAZARDS}

$\begin{array}{llll}\square \text { Organic Chemical } & \text { X } & \text { Inorganic Chemical } & \square \text { Carcinogen } \\ \text { X Corrosive } & \square \text { Reactive } & \square \text { OSHA Specific } \\ \square \text { Mutagen } & \square \text { Teratogen } & & \text { Substances }\end{array}$

\subsection{IONIZING RADIOLOGICAL HAZARDS}

Internal Exposure $\quad \mathrm{X}$ External Exposure

\subsection{NON-IONIZING RADIOLOGICAL HAZARDS}

$\square \quad$ UV

$\square$ Laser
RF

Microwave

\subsection{BIOLOGICAL/VECTOR HAZARDS}

X Wildlife

Bacterial

$\begin{array}{ll}\square & \text { Plants } \\ \mathrm{X} & \text { Parasites }\end{array}$

Heavy Equipment Op.

Welding/Cutting 


\subsection{DESCRIPTION OF HAZARDS AND CONTROLS}

\subsubsection{Chemical bazards}

Tasks: Sampling Groundwater

Controls: Small quantities of acid (typically less than a milliliter of $2 \mathrm{~N}$ nitric or sulfuric acid) are used to preserve water samples in the field. Plastic bottles of acid $(<100 \mathrm{~mL})$ are labeled and personnel wear protective gloves and a face shield when dispensing the acid. A portable eyewash will be available at the site.

NOTE: MSDSs are attached and workers will be briefed on the hazards.

NOTE: previous sampling has documented that combustible gases are not present in the wells.

\subsubsection{Fire/Explosion}

Tasks: Sampling Groundwater

Are flammable liquids present? X Yes $\square$ No

Description: Gasoline powered electric generator.

Location: WAG 5

Quantity: 2 gallons

Containment/Storage method: Approved UL fireproof 2 gallon metal can.

For welding, cutting, or brazing, is Welding Permit required?

Yes X No (Not Applicable)

3.15.3 Confined/Enclosed Spaces (Not Applicable)

Tasks

Confined/enclosed space entry required (Low/High Risk)? $\square$ Yes $X$ No

Operations Safety Work Permit required? $\quad \square$ Yes $\mathrm{X}$ No

Standard Operating Procedure required? $\quad \square$ Yes $\mathrm{X}$ No

\subsubsection{Ionizing Radiation}

Tasks: Sampling groundwater.

Applicable detailed checklist? X Yes ${ }^{*} \square$ No $\square$ NA

Primary contaminating isotope(s) ${ }^{241} \mathrm{Am},{ }^{244} \mathrm{Cm},{ }^{238} \mathrm{Pu},{ }^{239240} \mathrm{Pu},{ }^{90} \mathrm{Sr},{ }^{3} \mathrm{H},{ }^{137} \mathrm{Cs},{ }^{60} \mathrm{Co}$ 
Location on site

Containment/Storage method: rad waste stored in carboy or barrel

Radiation type: Alpha/Beta/Gamma

Dose rate (maximum) ${ }_{*}^{*} \leq 3 \mathrm{mrem} / \mathrm{h} @ 30 \mathrm{~cm}$

(average) $0.1 \mathrm{mrem} / \mathrm{h}$

Worker dose limit: $20 \mathrm{mrem} /$ day

Contamination level: (fixed) (removable)

* will be surveyed by HP prior to work beginning will be surveyed by HP prior to work beginning

Airborne contamination concentration: ${ }^{*} 0 \mu \mathrm{Ci} / \mathrm{mi}$

Water contamination potential?

* X Yes $\square$ No

Unrestricted airborne contamination release potential?

Yes $\mathrm{X}$ No

Radiation work permit required? A RWP may be required for sampling at some locations, as advised by Health Physics

Health Physics coverage: " Conditional

Special task operation requirements: Not Applicable (N/A)

Welding/cutting/grazing

Grinding/chipping

Hydraulic/air hammer operation

Dusty conditions (sweeping, vacuuming, etc.)

Equipment decontamination/free release

\begin{tabular}{|c|}
\hline N/A \\
\hline $\mathrm{N} / \mathrm{A}$ \\
\hline N/A \\
\hline N/A \\
\hline N/A \\
\hline
\end{tabular}

* NOTE: Area HP and IH shall survey the work area prior to initiation of new work area and set any additional requirements for zoning and PPE. Controls for tritium contamination will include the use of 2 pairs of latex (surgical) gloves and Tyvek suits to prevent skin contact. A splash shield will be present at the site but its need is not anticipated due to the low splash potential of the sampling operation.

\subsubsection{Nonionizing Radiation}

Tasks: Sampling groundwater

High-Voltage electrical transmission lines nearby?

Yes X No

Location, distance and voltage: No overhead lines or underground utilities are present at sampling sites

Radio frequency radiation sources (AM and/or FM broadcast:

towers, $r-f$ sealers) nearby?

Yes X No 
Location and distance:

Microwave sources in use on site?

Yes X No

Location and distance:

Lasers in use nearby?

Yes $\mathrm{X}$ No

Location and laser class:

Are workers potentially exposed to sunlight (ultraviolet radiation)? X Yes $\square$ No

Are ultrasound sources in use on site?

Yes $\mathrm{X}$ No

Location:

\subsubsection{Electrical Hazards}

Tasks: Sampling groundwater

Electrical shock hazard?

$\mathrm{X}$ Yes $\square$ No

\begin{tabular}{c}
$120 \mathrm{~V}$ \\
\hline Vomps \\
\hline
\end{tabular}

Location of hazard: Portable generator

Precautions: A Ground-Fault Interrupter circuit will be used in conjunction with wellinsulated electrical cord for all electrical connections.

\subsubsection{Temperature Extremes}

Tasks: Sampling groundwater

Temperature extremes (Hot/Cold $)$ ?

$\mathrm{X}$ Yes $\square$ No

95 Average daily high temperature (during work shift) ${ }^{\circ} \mathrm{F} /{ }^{\circ} \mathrm{C}$

30 Average daily low temperature (during work shift) ${ }^{\circ} \mathrm{F} /{ }^{\circ} \mathrm{C}$

- Temperature WBGT ${ }^{\circ} \mathrm{C}$ (obtain from IH prior to daily activities, as necessary)

Work load:

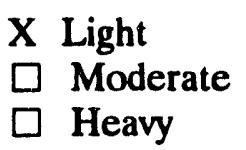

Precautions (specify): The SSHO will contact IH for guidance/requirements. For hot conditions, the SSHO will establish appropriate work/rest regime. For cold weather appropriate clothing and work schedules will be utilized

Cooling/heating equipment needed: As required by weather conditions

\subsubsection{Noise}

Tasks Sampling groundwater 
Noise extremes?

Yes $\mathrm{X}$ No

Sound level:

$\mathrm{dB}(\mathrm{A})$

Noise source(s):__ gasoline generator

Noise above $85 \mathrm{~dB}(\mathrm{~A})$ (hearing protection required):

Yes $\mathrm{X}$ No

Precautions (specify): Monitoring by IH demonstrated noise is not a problem at distances greater than 1 -foot from the generator. Personnel will be approximately $5 \mathrm{ft}$ from the generator during routine operation

\subsubsection{Vibration (not applicable)}

Tasks

Precautions (specify):

\subsubsection{Sanitation}

Tasks Sampling groundwater

Potable water required? Yes.

Non-potable water used? No.

Decontamination: buckets and water will be present at the sampling site for decontamination. Any materials in contact with groundwater (e.g., sampling tubing or $\mathrm{pH}$ electrodes) will be rinsed with water, wiped and frisked. Any contamination on personnel identified by frisking will be decontaminated using buckets and water. Because of the history of the site, the risk of chemical contamination is minute.

Eating, drinking, and smoking permitted? Drinking only.

Location: In areas designated by area HP

Toilet facilities required? Yes.

Location and number: In building 7831

Washing facilities required? No.

Location: In building 7831

Change rooms required? No.

Specify:

\subsubsection{Illumination}

Tasks Groundwater sampling

All tasks will be conducted during daylight hours.

Additional illumination needed?

Yes X No $\square$ NA 


\subsubsection{Safety Hazards}

Site posted information/notification required?

X Yes $\square$ No $\square$ NA

Site posting required?

$\mathrm{X}$ Yes $\square$ No

Site guard required?

$\square$ Yes X No $\square$ NA

Access control required?

$\mathrm{X}$ Yes $\square$ No

Entry/exit logs required?

$\mathrm{X}$ Yes $\square$ No

Note: logging in by badge reader at entrance to SWSA, as well as additional logging as required by any $R W P$

Escape routing/posting required (include site map)?

$\mathrm{X}$ Yes $\square$ No

Compressed gas cylinders?

$\square$ Yes $\mathrm{X}$ No

Location:

Storage:

\subsubsection{Biological Hazards}

Insect and tick repellant will be used as appropriate. Cans of wasp spray will also be available in case needed. 


\section{TASK BREAKDOWN}

(Provide detailed description, controls, and requirements for each task to be performed, i.e., drilling, sampling, etc.)

\section{Site Control}

Site work zones are required to reduce the accidental spread of hazardous substances from contaminated areas to clean areas. The identification of the zones will provide for control of operations and flow of personnel. The HPC will provide signs to be posted at the site for HAZWOPER requirements. The HP will determine radiological postings. Should additional barriers (rope, tape) or signs be required, HP, IH, and IS will be consulted. Personnel accessing the zones must meet access requirements as stated in this plan and at entrance of the zones. The SSHO is responsible for ensuring all workers and visitors meet site access requirements. Section 8 is a record of site access requirements and personnel qualifications.

Use of the buddy system is required for this project. All workers will have a partner to work with. To ensure worker safety, personnel will maintain (1) internal communication, (2) line of sight with other workers, and (3) work party monitoring. The access control point into the radiological zones will be where the buddy system is implemented. A two-way radio will be maintained in the clean, support zone to ensure communication with the Laboratory Shift Superintendent and emergency, safety, and health support personnel.

A breakdown of tasks involved in groundwater sampling, along with the hazards and controls is attached as Appendix B.

\subsection{TASK DESCRIPTION}

Type of Work:

Intrusive

$\mathrm{X}$

Non-intrusive

Engineering Controls:

Administrative Controls: training, applicable permits, postings, access controls, and altered work schedules as indicated

(Required permits, training, etc.):

Initial Level of Personal Protective Equipment:

$\begin{array}{lllll}\text { Level of Protection: } & \text { ( ) A } & \text { ( ) C } & \text { (X) Modified } & \text { Respirator not required. } \\ & \text { ( ) B } & \text { (X) D } & \end{array}$

Respirator: （）SCBA （）Fullface（）1/2 Face Resp.

Cartridge: 
Protective Clothing:

( ) Encapsulating Suit
( ) Saranex
( ) C-zone
( ) Other

(X) Tyvek*

( ) Splash suit

(X) Company Clothing (khakis)

Head/eye/ear:
( ) Hard Hat
(X) Safety Glasses
(X) Splash Shield**
( ) Ear Plugs
( ) Goggles

*A splash shield will only be worn when dispensing acid as a sample preservative.

Gloves:
( ) Nitrile
( ) Neoprene
( ) PVC
(X) Latex***
( ) Vinyl
( ) Leather
( ) Other

Footwear:

(X) Steel-toed leather ( ) Chemical overboots

( ) Steel-toed rubber (X) Other rubber boots

Additional comments: Each seep and each well shall be initially evaluated by the HP/IH before sampling activities occur. Groundwater sample containers will be monitored at the HP office prior to leaving WAG 5 to determine that the samples do not exceed guidelines.

Modifications allowed: In accordance with RWP, if required.

* Tyvek suits will be required to work in known or suspected areas of tritium contamination.

** A splash shield will only be worn when dispensing acid as a sample preservative.

*** Latex surgical gloves will be worn in layers when working in areas of suspected radiological contamination. 


\section{MONITORING REQUIREMENTS}

\subsection{DIRECT READING INSTRUMENTS}

\begin{tabular}{|c|c|c|c|}
\hline & Task(s) & $\begin{array}{l}\text { Monitoring } \\
\text { Frequency }\end{array}$ & $\begin{array}{l}\text { Action } \\
\text { Guidelines }\end{array}$ \\
\hline LEL Meter & see note 1 & prior to sampling & $10 \%$ LEL \\
\hline $\begin{array}{l}\mathrm{O}_{2} \text { Meter } \\
\text { Colorimetric Indicator Tubes }\end{array}$ & & $\begin{array}{l}\text { prior to sampling } \\
\text { prior to sampling }\end{array}$ & $\frac{>22 \% \mathrm{O}_{2}}{1 / 2 \mathrm{PEL}}$ \\
\hline Photoionization Detector (PID) & see note 1 & prior to sampling & $5 \mathrm{ppm}$ \\
\hline Flame Ionization Detector (FID) & see note 1 & prior to sampling & $5 \mathrm{ppm}$ \\
\hline
\end{tabular}

Alpha and Beta/Gamma meters will be the primary monitoring instruments. Personnel and equipment will be frisked prior to exiting the sampling site and controlled access area. Radiological hazards are the only hazards anticipated, based on the history of the site and the results of previous sampling as noted in Sect. 1. Those hazards will be assessed using alpha and beta/gamma meters. Frisking will be conducted during sampling if there is reason to suspect contamination (e.g., a splash). If an activity of $>100 \mathrm{cpm}$ above background for betagamma and $>300 \mathrm{dpm} / 100 \mathrm{~cm}^{2}$ for alpha is detected, the HP will be contacted for further instructions.

Area Radiation Monitors

Noise Meter

Other (PCM-113)

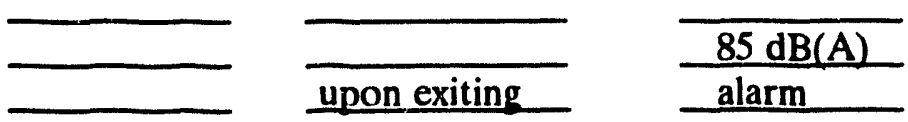

\subsection{PERSONAL MONITORING}

\begin{tabular}{|c|c|c|c|}
\hline \multicolumn{4}{|l|}{ Whole-body Dosimetry } \\
\hline Extremity Dosimetry & & & IAW HP Manual \\
\hline $\begin{array}{l}\text { Whole-body Count } \\
\text { Urinalusis/Bioassay }\end{array}$ & Sampling & $\begin{array}{l}\text { prior to starting } \\
\text { prior to starting }\end{array}$ & $\frac{\text { IAW HP Manual }}{\text { IAW HP Manual }}$ \\
\hline Chemical Air Sampling & Damipinie & Not required & \\
\hline Radiation Air Sampling & & Not required & \\
\hline
\end{tabular}

Instruments used by IH representative will be calibrated and maintained in accordance with IH Standard Operating Procedure, SOP-IH-25.1, Administration of the Instrument Calibration Program. Instruments used by the Office of Radiation Protection are calibrated and source checked in accordance with the ORNL Health Physics Manual, RP-1.6, Health Physics Instruments.

Note 1: Due to the history of the site and based on the results of previous monitoring of the groundwater at the site, the risk of chemical contamination is minute. Combustible gases have not been found when any of the wells were opened during previous samplings. If any other contaminants are detected by IH, sampling of that well will not occur until IH has evaluated the hazard by collecting a sample and identifying the chemical hazard. 
NOTE: All persons exiting WAG 5 shall perform a half body frisk with the half-body monitor (PCM-113) in Building 7831. 


\section{DECONTAMINATION}

The purpose of decontamination is to prevent contaminants that may be present on protective clothing and equipment from coming into contact with personnel as they un-suit. Also, decontamination protects workers from hazardous substances that may contaminate and eventually permeate the PPE used on site; it protects personnel by minimizing the transfer of harmful materials into clean areas. Combining decontamination with the correct sequential method of removing personal protective equipment will prevent exposure to personnel leaving the work areas as well as off-site migration of contaminants. Generally, decontamination is accomplished by starting with the most heavily contaminated item and progressing to the least contaminated item.

Personnel will remove any disposable PPE and dispose it in provided containers before leaving the radiological area. The Radiation Protection representative will assist the SSHO in establishing stations and sequence for doffing of PPE. Monitoring (frisking) of personnel and equipment prior to exiting contaminated areas will be conducted by the SSHO.

Upon job completion, all equipment will be surveyed by ORNL Radiation Protection and tagged accordingly. If contamination is detected on equipment, the equipment will be cleaned with a paper towel. Equipment that cannot be decontaminated will be bagged and disposed of in accordance with instructions from the Office of Radiation Protection representative.

Decontamination will also include contamination avoidance, which will include measures such as the use of disposable plastic to protect instrument surfaces and avoiding contact with contaminated equipment to the degree practical. Also the tubing in the well will be dedicated to that well and will not need decontamination. The hollow fiber filters used for the particle size separation will be placed in a plastic bag and brought back to the lab for cleaning and decontamination. All electrochemical probes such as $\mathrm{pH}$ meter probes, water level probes, etc. will be rinsed with DI water. This waste water will be collected in an appropriate container and disposed of as low level radioactive waste. 


\section{EMERGENCY PREPAREDNESS}

A list of potential hazards is described in Section 3, and the controls for, and response to, those hazards attached as Appendix B.

The responsibility of day-to-day implementation of this information primarily lies with the SSHO. During an actual emergency response situation, the SSHO will serve as the Emergency Coordinator until the Laboratory Shift Superintendent or emergency response team arrives.

Medical assistance will be provided by the Health Division, which is located at Building 4500-North. The LSS will provide emergency response personnel and coordinate emergency assistance. The radio number for the LSS is Station 103. The telephone number for the LSS is 574-6606. In the event that the LSS is not available, emergency services may be reached at the telephone numbers shown below.

The SSHO will perform the following pre-emergency tasks before starting field activities and will coordinate emergency response with the LSS:

1. Locate nearest telephone and alarm station.

2. Confirm and post emergency telephone numbers.

3. Post site map of work areas marked with evacuation routes.

4. Inventory and check out on-site emergency equipment and supplies, as warranted.

In the event of an emergency that requires evacuation of the site, a verbal instruction will be given by the SSHO to evacuate the area. Personnel will exit to a predesignated support area. At this point, the SSHO will account for all personnel, ascertain information about the emergency, and advise further instructions to the on-site personnel. In all situations that require evacuation, personnel shall not reenter the work area until the conditions causing the emergency have been corrected, the hazard reassessed, the Work Plan and SSHP revised, approved, and reviewed with on-site personnel, and inst uctions given for re-entry.

The project personnel at the site will have a radio or cellular telephone available at the site to contact emergency personnel.

\begin{tabular}{lcc}
\hline Emergency Personnel & Phone & Radio Number \\
\hline ORNL Emergency Response & 911 & \\
Laboratory Shift Superintendent & $574-6606$ & 103 \\
Fire Department & $574-5678$ & \\
Medical Center & $574-7431$ & \\
Security & $576-5064 / 576-1367$ \\
Industrial Hygiene & $574-6700$ & \\
Industrial Safety & $574-8770$ \\
Radiation Protection & & \\
Environmental Compliance & & \\
Waste Management and & Remedial Action & \\
\hline
\end{tabular}




\section{TRAINING REQUIREMENTS}

All site personnel and visitors requiring access to the work zones will be required to have current 24 hour HAZWOPER (SARA/OSHA) training and annual refresher, and Radiation Worker Training. Note: list all other training/medical requirements. If site conditions change, or other hazards are detected, the training and access requirements will be revised accordingly. If respiratory protection is required for sampling a site, workers will require 40-hour SARA/OHSA training and respirator fitting and training will be required.

Site Personnel Qualifications:

Name: J. Daniel Marsh

Badge number: 27615

Assigned tasks: Sampling groundwater/alternate STL and SSHO

\begin{tabular}{|c|c|c|c|}
\hline & YES & $\underline{\text { NO }}$ & DATE \\
\hline 40 hr. training: & $\mathbf{x}$ & $\square$ & $7 / 22 / 91$ \\
\hline 24 hr. training: & $\mathbf{X}$ & $\square$ & $6 / 28 / 90$ \\
\hline Annual Refresher Training: & $\mathbf{x}$ & $\square$ & $1 / 7 / 93$ \\
\hline Supervisor training: & $\mathbf{x}$ & $\square$ & $11 / 28 / 91$ \\
\hline Confined space entry training: & $\square$ & $\mathbf{x}$ & \\
\hline Radiation worker: & $\mathbf{x}$ & $\square$ & $6 / 93$ \\
\hline Respirator fit tested/trained: & $\square$ & $\mathbf{x}$ & \\
\hline Medical Surveillance Program: & $\mathbf{x}$ & $\square$ & $8 / 1 / 93$ \\
\hline
\end{tabular}

Name: J. F. McCarthy Badge number: $\underline{23942}$

Assigned tasks: sampling groundwater

\begin{tabular}{|c|c|c|c|}
\hline & YES & $\underline{\text { NO }}$ & DATE \\
\hline $40 \mathrm{hr}$. training: & $\square$ & $\mathbf{X}$ & \\
\hline $24 \mathrm{hr}$. training: & $\mathbf{X}$ & $\square$ & $1 / 18 / 90$ \\
\hline Annual Refresher Training: & $\mathbf{X}$ & $\square$ & $4 / 29 / 93$ \\
\hline Supervisor training: & $\square$ & $\mathbf{X}$ & \\
\hline Confined space entry training: & $\square$ & $\mathbf{X}$ & \\
\hline Radiation worker: & $\mathbf{x}$ & $\square$ & $6 / 15 / 93$ \\
\hline Respirator fit tested/trained: & $\square$ & $\mathbf{X}$ & \\
\hline Medical Surveillance Program: & $\mathbf{X}$ & $\square$ & $8 / 1 / 93$ \\
\hline
\end{tabular}


Name: Jennifer McDonald

Badge number: 623975

Assigned tasks:

sampline groundwater/STL and SSHO

$40 \mathrm{hr}$. training:

$24 \mathrm{hr}$. training:

Annual Refresher Training:

Supervisor training:

Confined space entry training:

Radiation worker:

Respirator fit tested/rained:

Medical Surveillance Program:

Other training:

\begin{tabular}{|c|c|c|}
\hline YES & NO & DATE \\
\hline $\mathbf{x}$ & $\square$ & $7 / 30 / 93$ \\
\hline $\mathbf{x}$ & $\square$ & $5 / 14 / 93$ \\
\hline$\square$ & $\mathbf{x}$ & \\
\hline $\mathbf{X}$ & $\square$ & $7 / 27 / 93$ \\
\hline$\square$ & $\mathbf{x}$ & \\
\hline $\mathbf{x}$ & $\square$ & $7 / 2,93$ \\
\hline $\mathbf{x}$ & $\square$ & $7 / 30 / 93$ \\
\hline $\mathbf{x}$ & $\square$ & $8 / 1 / 93$ \\
\hline
\end{tabular}

Name: Lynn Webster

Badge number: 625335

Assigned tasks: sampling groundwater

\begin{tabular}{llll}
\hline & YES & NO & DATE \\
\cline { 2 - 4 } 24 hr. training: & $\square$ & $\mathbf{X}$ & \\
Annual Refresher Tiaining: & $\mathrm{X}$ & $\square$ & $\underline{5 / 14 / 93}$ \\
Supervisor training: & $\square$ & $\mathbf{X}$ & \\
Confined space entry training: & $\square$ & $\mathbf{X}$ & \\
Radiation worker: & $\square$ & $\mathrm{X}$ & \\
Respirator fit tested/trained: & $\mathrm{X}$ & $\square$ & $\underline{7 / 293}$ \\
Medical Surveillance Program: & $\mathrm{X}$ & $\mathrm{X}$ & \\
Other training: & & & \\
\hline
\end{tabular}

Name: Traci Knowles

Badge number: 624135

Assigned tasks: sampling groundwater

$40 \mathrm{hr}$. training:

$24 \mathrm{hr}$. training:

Annual Refresher Training:

Supervisor training:

Confined space entry training:

Radiation worker:

Respirator fit tested/trained:

Medical Surveillance Program:

$\begin{array}{ccc}\text { YES } & \text { NO } & \text { DATE } \\ \square & \mathrm{X} & \\ \mathrm{X} & \square & 5 / 14 / 93 \\ \square & \mathrm{X} & \\ \square & \mathrm{X} & \\ \square & \mathrm{X} & \\ \mathrm{X} & \square & \underline{5 / 2193} \\ \square & \square & \\ \mathrm{X} & \square & \mathbf{8 / 1 9 3}\end{array}$

Other training: 
Name: Tony Thomas

Badge number: 17401

Assigned tasks: sampline groundwater

$40 \mathrm{hr}$. training:

24 hr. training:

Annual Refresher Training:

Supervisor training:

Confined space entry training:

Radiation worker:

Respirator fit tested/trained:

Medical Surveillance Program:

Other training:

\section{DATE}

2/3/89

$5 / 10 / 88$

$7 / 19 / 93$

$\mathbf{X} \square$

$\square \quad \mathbf{x}$

$\square \quad \mathbf{x}$

$\mathrm{x} \quad \square$

$\square \quad \mathbf{x}$

X $\square \quad \mathbf{8 / 1 9 3}$

Name: Baohua Gu

Badge number:

Assigned tasks: sampling groundwater

\begin{tabular}{llll}
\hline & YES & NO & DATE \\
24 hr. training: & $\square$ & $\square$ & \\
Annual Refresher Training: & $\mathrm{X}$ & $\square$ & $\underline{5 / 14 / 93}$ \\
Supervisor training: & $\square$ & $\square$ & \\
Confined space entry training: & $\square$ & $\square$ & \\
Radiation worker: & $\square$ & $\square$ & $\overline{7 / 30 / 93}$ \\
Respirator fit tested/trained: & $\mathrm{X}$ & $\square$ & $\underline{8 / 193}$ \\
Medical Surveillance Program: & $\mathrm{X}$ & $\square$ & $\underline{ }$ \\
Other training: & & & \\
\hline
\end{tabular}

NOTE: All workers are on the ORNL Medical Surveillance Program. The HAZWOPER Program Coordinator will determine if workers need to be placed on the ORNL HAZWOPER Medical Surveillance Program. 
APPENDIX A

WAG 5 Existing Data 

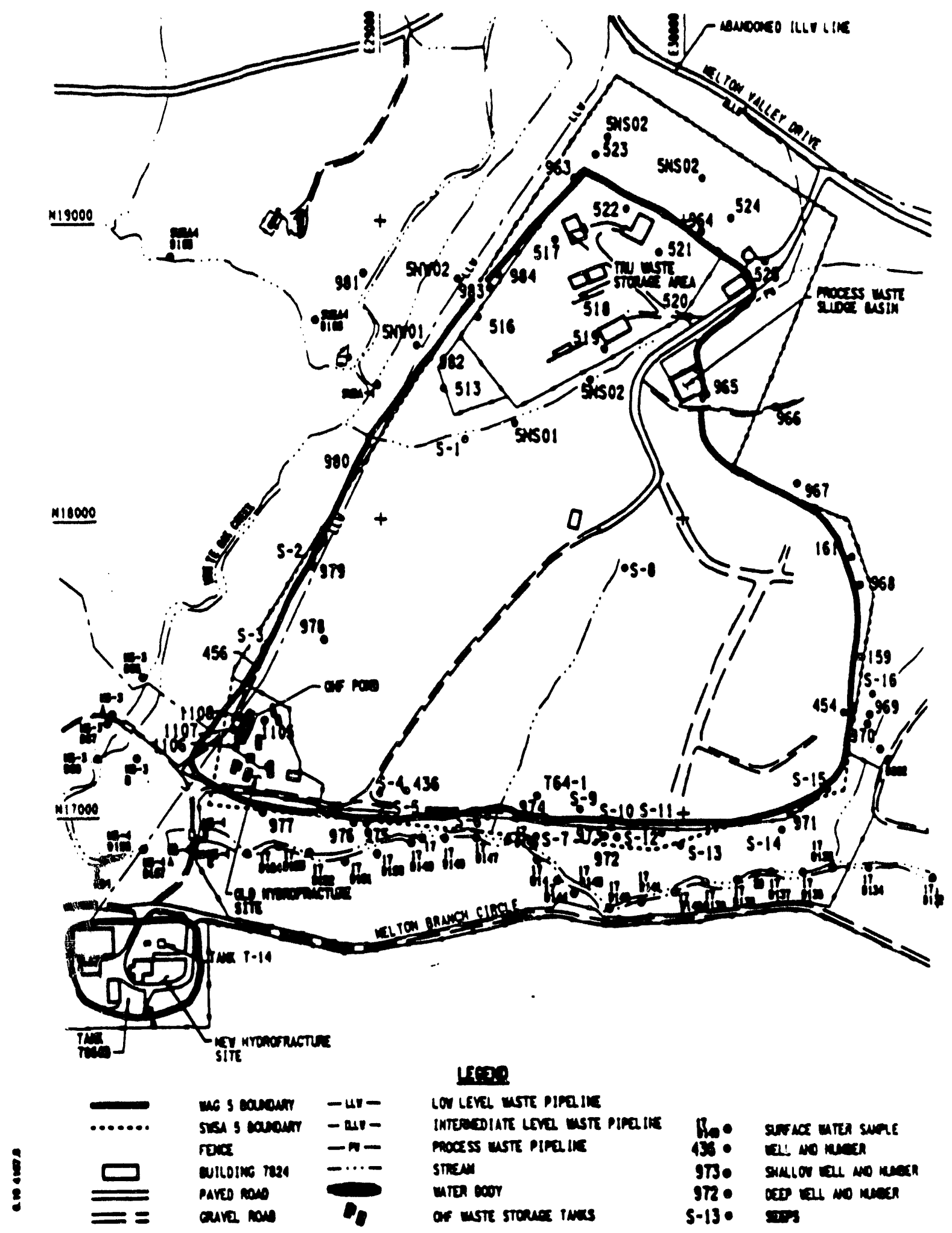

Fig. A-1. WAG 5 existing data locations. 


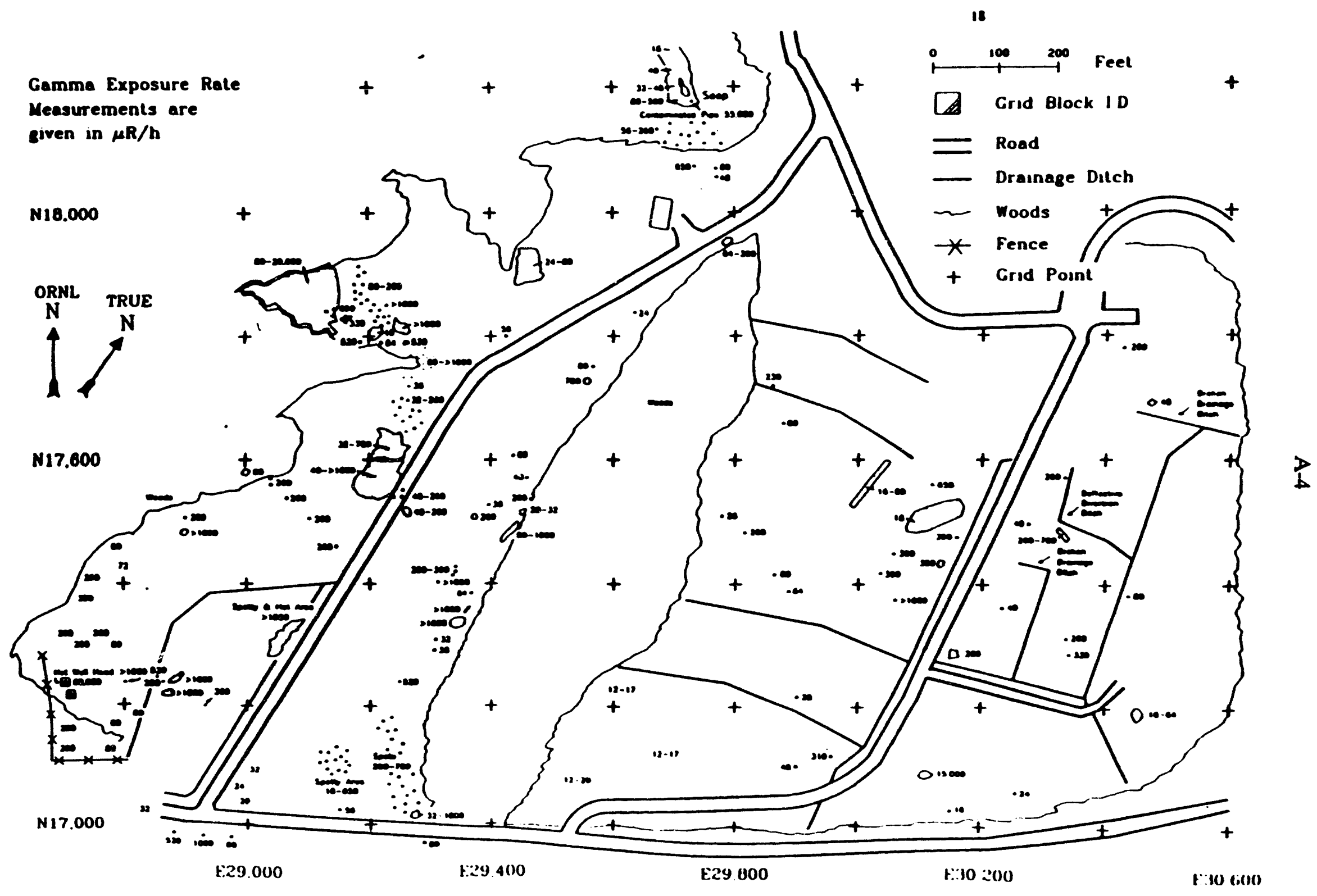

Fig. A-2 March 1988 radiological walkover survey of SWSA 5. 


\section{APPENDIX B}

Tasks, Hazards, and Controls 
Table B-1. List of tasks, hazards, and controls

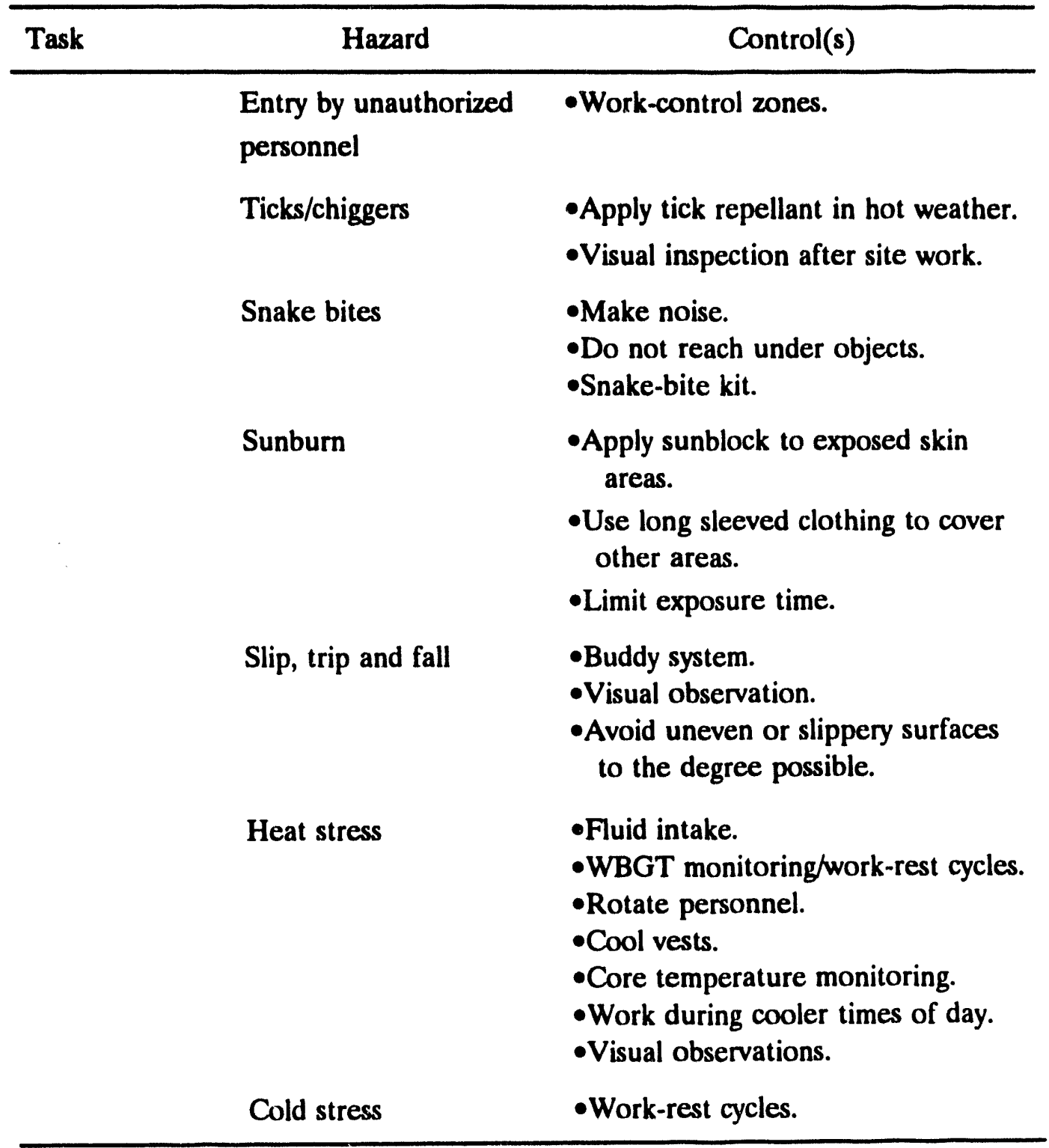




\section{APPENDIX C}

Material Safety Data Sheets 
Martin Marietta Energy Systems, Inc. Material Safety Data Sheet

RECID:

CAS No:

Material Name:

Synonyms :

status Information:

Modification History:

Special Condition: HM Group Code : MMES Carcinogen:

RTECS Reproductive/ Developmental Effector:

AVID No:

Stores No:

Pure Chemical:

Chemical Formula:

1. IDENTIFICATION

00870

007647-01-0

HYDROCHLORIC ACID

1) AQUEOUS HYDROGEN CHLORIDE

2) EM SCIENCE CATALOG NUMBERS: HX0603, HX0603I, HX0603P, HX0603Y, HX0603T

3) EM SCIENCE CATALOG NUMBERS: HX0603TP, 314, 315, 317

4) EM SCIENCE HCL (APPROX, $37 \%$ IN WATER)

5) FISHER SCIENTIFIC CATALOG NUMBER: A144S212

6) FISHER SCIENTIFIC HYDROCHLORIC ACID, CONCENTRATED $(36-378)$

7) HYDROCHLORIC ACID GAS

8) HYDROCHLORIC ACID, ANHYDROUS

9) JT BAKER PRODUCT CODES: 5800, 5214, 5575, 9543, 9530

10) JT BAKER PRODUCT CODES: 9538, 9537, 9535, 4800, $9542,9534,5537,9549,9529$

11) JT BAKER PRODUCT CODES : 9547, 9546, 6900, 9536, $9540,9539,9548,5367,9544$

12) LIQUID AIR CATALOG NUMBERS: 0039-3900, 0040-4000

13) MALLINCKRODT HYDROCHLORIC ACID, 37\%

14) MURIATIC ACID

15) MURIATIC ACID, 23 DEG. BE

\begin{tabular}{cccc} 
MSDS & MSDS & MSDS & $\begin{array}{c}\text { Request } \\
\text { Type }\end{array}$ \\
Status & Available & Outstanding \\
\hline D & A & Yes & No
\end{tabular}

\begin{tabular}{ccc} 
Date of Entry & Date of Change & Last Modifier \\
\hline $09 / 24 / 1993$ & $09 / 24 / 1993$ & THI
\end{tabular}

N

C

No or Not Yet Determined

Yes

\begin{tabular}{|c|c|c|c|}
\hline $\begin{array}{l}\text { GSCO039-35 } \\
\text { LBCJT6900 } \\
\text { LBCMRJT } 95 \\
\text { LBC6900-0 } \\
\text { LBCJT } 9530 \\
\text { LBCJT } 9535\end{array}$ & 5 & $\begin{array}{l}\text { GSC0040-4000 } \\
\text { LBCJT } 9530-33 \\
\text { LBCMRJT 9535 } \\
\text { LBCJT } 9535-03 \\
\text { LBCJT } 9534-6 \\
\text { LBCJT } 9535-3\end{array}$ & -33 \\
\hline 030011324 & 030011354 & 039507115 & 030011325 \\
\hline
\end{tabular}


Health Hazard Rating:

Fire Hazard Rating:

Reactivity Hazard Rating:

EPA ID No:

Physical Form:

Use :

RTECS NO:

Manufacturers:
3 , <HIGH HEALTH HAZARD>

CORROSIVE, IRRITANT

0 , <NONCOMBUSTIBLE>

0 , <NONREACTIVE >

NISS

LIQUID, GAS

ANALYTICAL REAGENT, CHEMICAL INTERMEDIATE ACIDIFYING AGENT

MW4025000

(Name, Address, Phone, FAX No, Contact)

1) AIDRICH CHEMICAL CO., INC.

P.O. BOX 355, MILWAUKEE, WI 53201

Phone: (414)273-3850, FAX: (414)273-4979

2) E.M. SCIENCE, INC.

DIVISION OF EM INDUSTRIES

P.O. BOX 70, 480 DEMOCRAT RD

GIBBSTOWN, NJ 08027

Phone: (609) 354-9200

Phone: (800)424-9300

3) FISHER SCIENTIFIC CHEMICAL COMPANY

P.O. BOX 4829, 5775 PACIFIC DRIVE, NORCROSS, GA 30091

Phone: $(404) 449-5050$

4) J.T. BAKER CHEMICAL COMPANY

222 RED SCHOOL LANE, PHILLIPSBURG, NJ 08865

Phone: EMERGENCY: (908)859-2151

Phone: 1-800-582-2537

5) LIQUID AIR CORP.

ONE CALIFORNIA PLAZA, SUITE 350, $2121 \mathrm{~N}$.

CALIFORNIA BLVD.,

WALNUT CREEK, CA' 94596

Phone: (800)231-1366

6) MATHESON CO

P.O. BOX 85, EAST RUTHERFORD, NJ 07073

Phone: (201) 933-2400

7) MALLINCKRODT, INC.

PARIS BY-PASS, P.O. BOX M, PARIS, KY 40361-0305 Phone: (606)987-7000, EMERGENCY: (314)982-5000

8) INFORMATION SUPPLIED BY ONCOR(R) MATERIAL SAFETY DATA SHEETS.FOR ADDITIONAL DA

MSDS Listing:

MFR MSDS

MSDS

Used

To Modify 


\section{C-5}

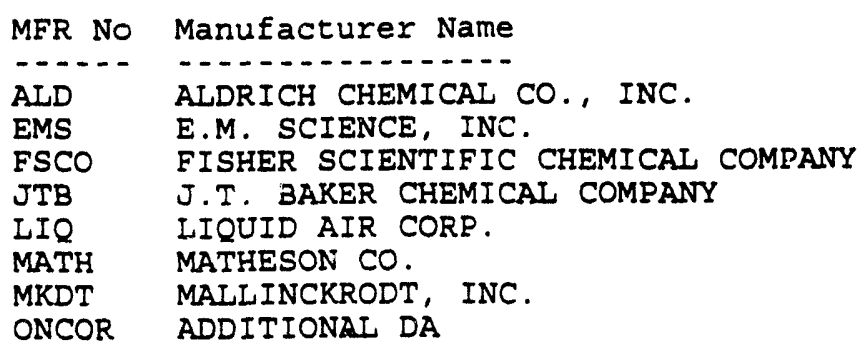

\begin{tabular}{llc} 
Prep Date & Rcvd Date & Tech Data \\
\hline $11 / 02 / 1989$ & $03 / 19 / 1992$ & Yes \\
$10 / 27 / 1987$ & $03 / 19 / 1992$ & Yes \\
$04 / 12 / 1991$ & $06 / 25 / 1991$ & Yes \\
$03 / 09 / 1992$ & $01 / 14 / 1993$ & No \\
$10 / 01 / 1985$ & $03 / 19 / 1992$ & Yes \\
$10 / 01 / 1985$ & $03 / 19 / 1992$ & Yes \\
$09 / 10 / 1986$ & $03 / 19 / 1992$ & Yes \\
$03 / 01 / 1989$ & $03 / 19 / 1992$ & Yes
\end{tabular}

2. PHYSICAL DATA $\ldots . . .$.
Material Description:

Molecular Weight:

Density/Specific Gravity:

Vapor Density:

Vapor Pressure:

Boiling Point :

Melting point:

Freezing Point:

Percent Volatiles:

Solubility in water: Evaporation Rate:
COLORLESS, FUMING GAS OR CLEAR, COLORLESS FUMING LIQUID. SHARP, PUNGENT, SUFFOCATING ODOR. ANHYDROUS HCL GAS HYDROLYZES RAPIDLY TO LIQUID HCL.

\subsection{6}

$1.187 \mathrm{G} / \mathrm{CC}$ AT - 121 DEG F, -85 DEG C FOR LIQUID; $1.00045 \mathrm{G} / \mathrm{L}$ FOR GAS

1.3 (AIR=1)

4 ATM AT 65 DEG F, 18 DEG C

-121 DEG F, -85 DEG C

-173 DEG F, -114 DEG C

NISS

NISS

SOLUBLE

NISS

Name :

RECID:

PURE CHEMICAL

Percent Comments:

RTECS Reprod Effector: No or Not Yet Determined

MMES Carcinogen:

Hazard Evaluation:

4. FIRE AND EXPLOSION HAZARD DATA $\ldots \ldots$

Flash Point:

Autoignition:

Lower Flammability Limit: Upper Flammability Limit:

Extinguishing Media:
NONFLAMMABLE

NONFLAMMABLE

NONFLAMMABLE NONFLAMMABLE

WATER SPRAY/FOG, DRY CHEMICAL, CARBON DIOXIDE, OR EXTINGUISHING MEDIA SUITABLE FOR SURROUNDING MATERIAL. 


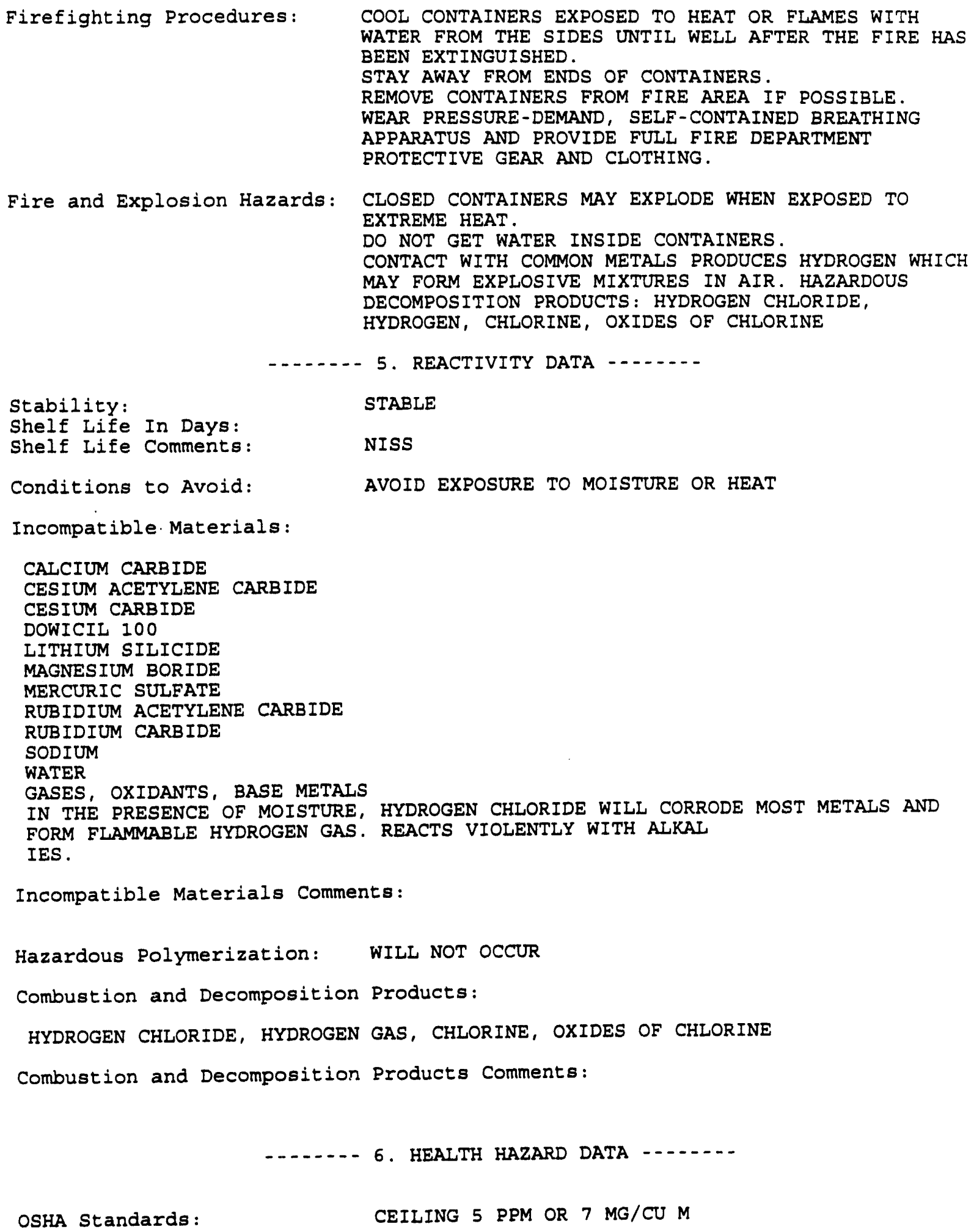


ACGIH TLV :

NIOSH Recommendation:

Immediately Dangerous to Life \& Health:

Other Exposure Limits:

Acute Inhalation:

Acute Swallowing:

Acute Skin Absorption:

Acute Skin Contact:

Acute Eye Contact:

Chronic Effects:

Target Organs/Systems :

Inhalation Emergency:

Swallowing Emergency:

Skin Contact Emergency:

Eye Contact Emergency:

Physicians Notes:

Aggravated Conditions:

Carcinogenicity:
CEILING 5 PPM OR 7.5 MG/CU M (1992-93)

NE

100 PPM

NISS

SEVERE IRRITATION AND/OR CHEMICAL BURNS TO NOSE AND UPPER AND LOWER RESPIRATORY TRACT,

LACRIMATION, COUGH, LABORED BREATHING. NECROSIS OF RESPIRATORY TRACT TISSUES, LUNG INJURY, CHEMICAI PNEUMONITIS, PULMONARY EDEMA. CIRCULATORY SYSTEM COLLAPSE.

HARMFUL AND MAY BE FATAL. CAUSES SEVERE CHEMICAL BURNS TO MOUTH AND STOMACH. MAY CAUSE NAUSEA AND VOMITING.

NISS

RAPIDLY CAUSES CHEMICAL BURNS, LESIONS, SCARRING, EARLY NECROSIS.

RAPIDLY CAUSES CHEMICAL BURNS, LESIONS, POSSIBLE LOSS OF VISION.

CORROSION OF TEETH.

NISS

REMOVE TO FRESH AIR AND GIVE ARTIFICIAL RESPIRATION IF NOT BREATHING. GET MEDICAL AID.

DO NOT INDUCE VOMITING. DILUTE STOMACH CONTENT WITH LARGE AMOUNT OF WATER OR MILK. GET MFDICAL AID.

REMOVE CONTAMINATED CLOTHING AND RINSE SKIN WITH RUNNING WATER FOR AT LEAST 15 MINUTES. GET MEDICAL AID.

FLUSH EYES AT ONCE WITH WATER FOR AT LEAST 15 MINUTES. GET MEDICAI AID.

\section{NISS}

PERSONS WITH IMPAIRED PULMONARY FUNCTION OR SKIN DISEASES MAY BE AT AN INCREASED RISK.

NISS

The MMES Carcinogen Control Program includes human, human suspect, and confirmed animal carcinogens. [See MMES Carcinogen: (Yes/No or Not Yet Determined) in Section 1.] Chemicals and compounds in concentration of $0.1 \frac{9}{8}$ or greater are subject to the guidelines set forth in the MMES Carcinogen Control program. Substitution with a non-carcinogen should be made if feasible. 
Genotoxicity:

NISS

Reproductive/Developmental

Toxicity: NISS

This section reflects materials listed in the Registry of Toxic Effects of Chemical Substances that have positive reproductive effects data for at l cast one mammalian species. Such effects may include paternal, maternal, fertility, embryo/fetus, neonatal, developmental abnormalities or tumorigenesis. An entry does not automatically imply that the substance is hazardous for common use. A hazard determination is generally required.

Spill or Leak Emergency:

SUMMON HELP IMMEDIATELY.

Y-12: SHIFT SUPERINTENDENT, 4-7172 OR 911

$X-10:$ SHIFT SUPERVISOR, 4-6606 OR 911

K-25: SHIFT SUPERVISOR, $4-3282$ OR 911

PADUCAH: SHIFT SUPERVISOR, BELL-6211, PAX-511

MINIMIZE THE SPILL OR RELEASE IF YOU CAN DO SO SAFELY.

EVACUATE THE AREA.

Disposal Procedure:

Y-12: TRANSFER STORAGE OR DISPOSAL OF WASTE PROCEDURE 70-903, DISPOSAL OF HAZARDOUS MATERIALS. FOR MORE INFORMATION, CONTACT THE WASTE DISPOSAL DEPARTMENT, $6-7768$.

X-10: WASTE, TRANSPORTATION, STORAGE, AND DISPOSAL MANUAL, EPM-8.0, FORM UCN-13696. FOR MORE INFORMATION, CONTACT THE DEPARTMENT OF ENVIRONMENTAL MANAGEMENT, $4-7467$.

K-25: SPP-4600, FORM UCN-12463. FOR MORE INFORMATION, CONTACT THE WASTE MANAGEMENT DIVISION, 4-8214.

PADUCAH: ESH-28, FORM UCN-12463A. FOR MORE INFORMATION, CONTACT THE WASTE MANAGEMENT DEPARTMENT, PAX-401 OR BELL-6319.

\section{$\ldots \ldots$. SPECIAL PROTECTION INFORMATION $\ldots \ldots . . .$.}

Respirators :

RESPIRATORS MAY BE REQUIRED WHEN USING THIS MATERIAL. CONTACT THE INDUSTRIAL HYGIENE DEPARTMENT FOR MORE INFORMATION.

Ventilation:

CONDITIONS, QUANTITIES, AND OTHER FACTORS DETERMINE

VENTILATION REQUIREMENTS. IF THERE ARE UNCERTAINTIES, CONTACT THE INDUSTRIAL HYGIENE DEPARTMENT.

Gloves:

WEAR CHEMICAL-RESISTANT GLOVES WHEN HANDLING LINES AND EQUIPMENT CONTAINING HYDROGEN CHLORIDE.

Eye Protection:

WEAR FACE SHIELD AND CHEMICAL WORKERS GOGGLES.

Other Protective Equipment:

SAFETY SHOES, SAFETY SHOWER, EYEWASH FOUNTAINS. HAVE POSITIVE-PRESSURE, SELF-CONTAINED BREATHING 
APPARATUS READILY AVAILABLE. HAVE AN EMERGENCY PLAN COVERING STEPS TO BE TAKEN IN THE EVENT OF AN ACCIDENTAL RELEASE. USE ONLY IN WELLVENTILATED AREAS.

Impurities, By-Products,

Contaminants: NISS

9. SPECIAL HANDLING, STORING, PACKAGING $\ldots \ldots .$.

STORE IN COOL, DRY, WELL-VENTILATED AREA. KEEP AWAY FROM INCOMPATIBLES. PROTECT FROM PHYSICAL DAMAGE. DO NOT ALLOW TEMPERATURE WHERE CYLINDERS ARE STORED TO EXCEED 130 DEG F (54 DEG C). USE SUITABLE HAND TRUCK FOR CYLINDER MOVEMENT. SHIPPED AS A LIQUIFIED GAS UNDER ITS OWN VAPOR PRESSURE. BEFORE USING THE GAS: 1. SECURE THE CYLINDER TO PREVENT IT FROM FALLING OR BEING KNOCKED OVER. 2. INSTALL CHECK VALVES OR TRAPS TO PREVENT SUCKBACK INTO THE CYLINDER. 3 . LEAK CHECK THE LINES AND EQUIPMENT.

10. TRANSPORTATION DATA

DOT Information:

(Name, Class, Label, Number)

1) HYDROGEN CHLORIDE NONFLAMMABLE GAS NONFLAMMABLE GAS; CORROSIVE, SOLUTION UN1050

2) HYDROCHLORIC ACID CORROSIVE MATERIAL NONFLAMMABLE GAS; CORROSIVE, SOLUTION UN1789

3) HYDROGEN CHLORIDE, REFRIGERATED LIQUID CORROSIVE MATERIAL NONFLAMMABLE GAS; CORROSIVE, SOLUTION UN1789

4) HYDROGEN CHLORIDE, ANHYDROUS CORROSIVE MATERIAL NONFLAMMABLE GAS; CORROSIVE, SOLUTION UN1789

Reportable Quantity: References:
NISS

- RTECS, REGISTRY OF TOXIC EFFECTS OF CHEMICAL SUBSTANCES (DATABASE). NATIONAL LIBRARY OE MEDICINE, BETHESDA MD.

- FIRE PROTECTION GUIDE ON HAZARDOUS MATERIALS, 9 TH ED., NATIONAL FIRE PROTECTION ASSOCIATION, BOSTON MA, 1986.

- MATERIAL SAFETY DATA SHEETS (MSDS) PROVIDED BY MANUFACTURERS.

- HSDB, HAZARDOUS SUBSTANCES DATA BANK (DATA BASE), NATIONAL LIBRARY OF MEDICINE, BETHESDA MD, 1990.

- IRVIN N. SAX. DANGEROUS PROPERTIES OF INDUSTRIAL MATERIALS; 6TH ED., VAN NOSTRAND REINHOLD COMPANY, 


\section{C-10}

NEW YORK, NY, 1984.

- 1984 EMERGENCY RESPONSE GUIDEBOOK. GUIDEBOOK FOR HAZARDOUS MATERIALS INCIDENTS, DEPARTMENT OF TRANSPORTATION.

- BAKER, C.J. THE FIREFIGHTER'S HANDBOOK OF HAZARDOUS MATERIALS 4TH ED., 1984. MALTESE ENTERPRISES, INC., INDIANAPOLIS IN 46231.

- HANDLING CHEMICALS SAFELY 1980, 2ND ED,. DUTCH ASSOCIATION OFSAFETY EXPERTS, THE DUTCH CHEMICAL INDUSTRY ASSOCIATION AND THE DUTCH SAFETY INSTITUTE, 1980.

- SCIENTIFIC REVIEW COMMITTEE FOR MSDS

WARNING: THE INFORMATION CONTAINED HEREON IS INTENDED SOLELY FOR THE USE OF EMPLOYEES OF MARTIN MARIETTA ENERGY SYSTEMS, INC.

THE INFORMATION IS NOT INTENDED TO BE A DEFINITIVE STATEMENT OF ALL HAZARDS ASSOCIATED WITH SAID MATERIAL OR ALL METHODS

OF COUNTERACTING HUMAN EXPOSURE TO SAME. USERS ARE CAUTIONED TO PROCEED WITH DUE CARE IN THE HANDLING, STORING AND DISPOSAL OF THIS MATERIAL AND TO SEEK FURTHER INFORMATION REGARDING PARTICULAR APPLICATIONS AS REQUIRED. MARTIN MARIETTA ENERGY SYSTEMS, INC.

P.O. BOX 2008

BLDG. 3550, MS 6291

OAK RIDGE, TENNESSEE 37831

PHONE : 615-574-0784

FAX: $615-576-6087$ 


\section{C-11}

Martin Marietta Energy Systems, Inc.

Material Safety Data Sheet

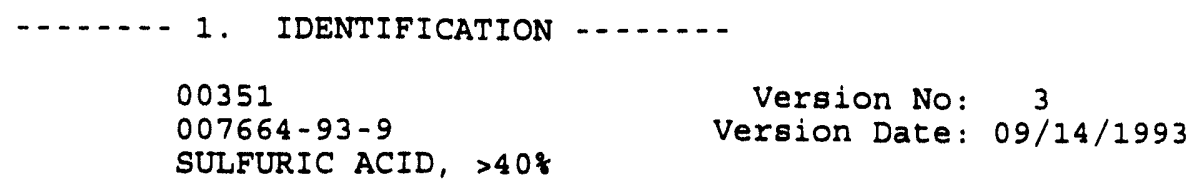

00351

007664-93-9

SULFURIC ACID, $>40 \%$

Version No: 3

Version Date: 09/14/1993

RECID :

CAS NO:

Material Name:

Synonyms :

Status Information:

Modification History:
1) $\mathrm{BOV}$

2) CHEMETRICS PHOSPHATE CHEMETS(R) AND VACU-VIALS(R)

3) CHEMETRICS SILICA ACTIVATOR SOLUTION

4) DIPPING ACID

5) DISULFURIC ACID

6) EM SCIENCE CATALOG NUMBERS: 14771, 14773

7) EM SCIENCE CATALOG NUMBERS: SX1242, SX1244, SX1244I，SX1244PC， SX1244Y，\#714

8) FISHER SCIENTIFIC CATALOG NUMBER: A3005212

9) HARCROS SULFURIC ACID 66BE BDY

10) HYDROGEN SULFATE

11) IPC MULE KICK LIQUID DRAIN CLEANER

12) JT BAKER PRODUCT CODES: 4802, 9691, 9674, 9676, $5340,5137,9673,5432,9688$

13) JT BAKER PRODUCT CODES: 9677, 9696, 5253

14) JT BAKER PRODUCT CODES: 9684, 9681, 6902, 5643, 9693, 9679, 9680, 9686

15) JT BAKER PRODUCT CODES: 9687, 5802, 5374, 9694, $9683,9675,5030,9682,9685$

16) JT BAKER PRODUCT CODES: 9705, 9699, 9703, 5691

17) LEEMAN LABS CATALOG NUMBER: 602-0006

18) MATTING ACID

19) MICROQUANT(R) AND SPECTROQUANT(R) NITRATE REAGENT NO. 2

20) NORDHAUSEN ACID

21) OIL OF VITRIOL

22) SPENT SULFURIC ACID

23) SULFURIC ACID SOLUTION $19.2 \mathrm{~N}$

24) SULFURIC ACID, $100 \%$

25) SULFURIC ACID, 40-50\%

26) SULFURIC ACID, 50-708

27) SULFURIC ACID, 60 DEG BE

28) SULFURIC ACID, 66 DEG BE

29) SULFURIC ACID, 77-998

30) SULFURIC ACID, 938

31) SULFURIC ACID, $95 \%$

32) SULFURIC ACID, $96 \%$

33) SULFURIC ACID, $98 \%$

34) SULFURIC ACID, 998

35) SULFURIC ACID, SPENT

36) SULPHURIC ACID

37) VITRIOL BROWN OII

\begin{tabular}{cccc} 
MSDS & MSDS & MSDS & $\begin{array}{c}\text { Request } \\
\text { Type }\end{array}$ \\
\hdashline Status & Available & Outstanding \\
D & A & Yes & No
\end{tabular}

Date of Entry Date of Change Last Modifier 
-

$09 / 13 / 1993$

N

Special Condition:

HM Group Code:

MMES Carcinogen:

RTECS Reproductive/

Developmental Effector:

AVID No:

Stores No:

Pure Chemical:

Chemical Formula:

Health Hazard Rating:

Fire Hazard Rating:

Reactivity Hazard Rating:

EPA ID NO:

Physical Form:

Use :

RTECS No:

Manufacturers :
Yes

Yes

LBC4 $802-4$

LBCMR JT $9681-33$

LBC9681-33

LBCJT4802-5

LBCEM - SX124 4 PC - 1

LBCJT9681-5
Yes

H2-O4-S

NISS

LIQUID

W55 600000

$$
09 / 14 / 1993
$$

THI
In Mist Form Only

LBCMR -009

LBCJT9673-0

LBC4 802

LBC6902-05

LBCJT $9681-4$

LBC9673-00

$030017212 \quad 030017257 \quad 330017257 \quad 030017258$

4, <EXTREME HEALTH HAZARD>

HUMAN CARCINOGEN, CORROSIVE, IRRITANT

0 , <NONCOMBUSTIBLE>

2, <MODERATELY REACTIVE>

MANUFACTURE OF FERTILIZERS, EXPLOSIVES, DYESTUFFS; MANUFACTURE OF OTHER ACIDS; PURIFICATION OF PETROLEUM; PICKLING OF METALS; DILUTE ACID IN GASTRIC HYPOACIDITY (MEDICINE)

(Name, Address, Phone, FAX No, Contact)

1) CHEMETRICS, INC.

ROUTE 28

CALVERTON, VIRGINIA 22016

Phone: (703) 788-9026

2) E.M. SCIENCE, INC.

DIVISION OF EM INDUSTRIES

P.O. BOX 70, 480 DEMOCRAT RD

GIBBSTOWN, NJ 08027

Phone: (609) 354-9200

Phone: (800)424-9300

3) FISHER SCIENTIFIC CHEMICAL COMPANY

P.O. BOX 4829, 5775 PACIFIC DRIVE, NORCROSS, GA 30091

Phone: (404)449-5050

4) INDUSTRIAL PETROLIC CORPORATION 
20-45 128TH STREET

COLLEGE POINT, NY

11356

Phone: $718-445-7900$

5) J.T. BAKER CHEMICAL COMPANY

222 RED SCHOOL LANE, PHILLIPSBURG, NJ 08865

Phone: EMERGENCY: (908)859-2151

Phone: $1-800-582-2537$

6) SIGMA CHEMICAL CO.

P.O. BOX 14508, ST. LOUIS, MO 63178

Phone: (800)325-5832, EMERGENCY: (314)771-5765

(CALL COLLECT)

7) TENNESSEE CHEMICAL COMPANY

3475 LENOX RD. NE, SUITE 670, ATLANTA, GA 30326

Phone: (404)233-681:

MSDS Listing:

\begin{tabular}{ll} 
MFR NO & Manufacturer Name \\
\hline CHEMET & CHEMETRICS, INC. \\
EMS & E.M. SCIENCE, INC. \\
FSCO & FISHER SCIENTIFIC CHEMICAL COMPANY \\
IPTC & INDUSTRIAI PETROLIC CORPORATION \\
JTB & J.T. BAKER CHEMICAL COMPANY \\
SIGMA & SIGMA CHEMICAL CO. \\
TENN & TENNESSEE CHEMICAL COMPANY
\end{tabular}

\begin{tabular}{lcc} 
MFR MSDS & MSDS & $\begin{array}{c}\text { Used } \\
\text { To Modify } \\
\text { Prep Date }\end{array}$ \\
Rcvd Date & Tech Data \\
\hline & $02 / 16 / 1993$ & No \\
$04 / 14 / 1988$ & $03 / 19 / 1992$ & Yes \\
$05 / 18 / 1990$ & $03 / 19 / 1992$ & Yes \\
$11 / 05 / 1986$ & $03 / 19 / 1992$ & No \\
$03 / 09 / 1992$ & $12 / 21 / 1992$ & No \\
$07 / 18 / 1986$ & $03 / 19 / 1992$ & Yes \\
$07 / 19 / 1989$ & $03 / 19 / 1992$ & Yes
\end{tabular}

2. PHYSICAL DATA -.....

Material Description:

COLORLESS TO DARK BROWN OILY LIQUID, ODORLESS, SOUR TASTE. ATTACKS MANY METALS RELEASING HYDROGEN, VERY HYGROSCOPIC.

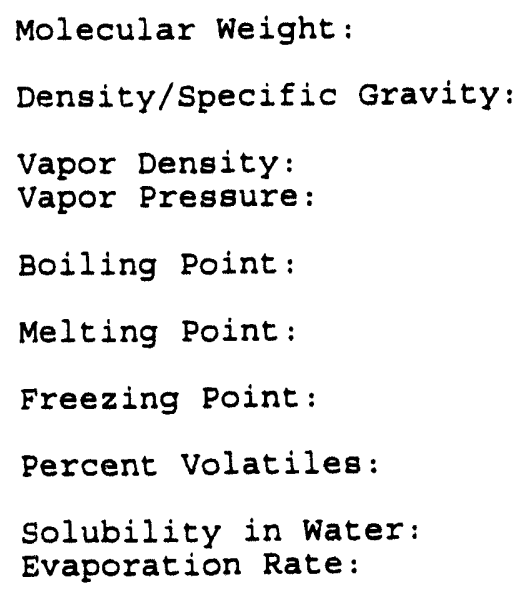


Name:

RECID

CAS NO:

PURE CHEMICAI

Percent Comments :

RTECS Reprod Effector: No or Not Yet Determined

MMES Carcinogen:

Hazard Evaluation:
$\ldots . . . .4$. FIRE AND EXPLOSION HAZARD DATA $\ldots . .$.
Flash Point:
NONFLAMMABLE
Autoignition:
NONFLAMMABLE
Lower Flammability Limit:
NONFLAMMABLE
Upper Flammability Limit:
NONFLAMMABLE
Extingulshing Media:
FIRES INVOLVING SMALL AMOUNT OF COMBUSTIBLES MAY BE SMOTHERED WITH SUITABLE DRY CHEMICAL. USE WATER ON COMBUSTIBLES BURNING IN VICINITY OF THIS MATERIAL BUT USE CARE AS WATER APPLIED DIRECTLY TO THIS ACID RESULTS IN EVOLUTION OF HEAT AND CAUSES SPLATTERING.

Firefighting Procedures:

DO NOT APPLY WATER ON MATERIAL ITSELF, AN ADVERSE REACTION IS POSSIBLE. USE FLOODING QUANTITIES OF WATER AS A FOG TO COOL ALL CONTAINERS INVOLVED IN FIRE. APPLY WATER FROM AS FAR A DISTANCE AS POSSIBLE. WEAR PRESSURE-DEMAND, SELF-CONTAINED BREATHING APPARATUS AND CHEMICAL PROTECTIVE SUIT.

Fire and Explosion Hazards:

NEGLIGIBLE EXPLOSION HAZARD WHEN EXPOSED TO HEAT OR FLAME. RUNOFF TO SEWER MAY CREATE FIRE OR EXPLOSION HAZARD. IGNITES COMBUSTIBLE MATERIAL ON CONTACT. REACTS WITH MOST METALS TO PRODUCE HYDROGEN GAS, WHICH CAN FORM AN EXPLOSIVE MIXTURE WITH AIR.

5. REACTIVITY DATA -...-

Stability:

Shelf Life In Days:

UNSTABLE

Shelf Life Comments:

NISS

Conditions to Avoid:

VIOLENT REACTION WITH MOISTURE.

Incompatible Materials:

ACETIC ANHYDRIDE, ACETONE CYANOHYDRIN, ACETONE AND POTASSIUM DICHROMATE, ACETONITRILE, ACROLEIN, ACRYLONITRILE, ALCOHOLS AND HYDROGEN PEROXIDE, ALLYL ALCOHOL, ALLYL CHLORIDE, 2-AMINOETHANOL, AMMONIUM HYDROXIDE, AMMONIUM TRIPERCHROMATE, ANILINE, BROMATES, BROMINE PENTAFLUORIDE, N-BUTYRALDEHYDE, CARBIDES, CESIUM ACETYLENE CARBIDE, CHLORATES, CHLORINE TRIFLUUORIDE, CHLOROSULFONIC ACID, CUPROUS NITRIDE, DI ISOBUTYLENE， DIMETHYLBENZYLCARB INOL, HYDROGEN PEROXIDE, EPICHLOROHYDRIN, ETHYLENE CYANOHYDRIN, ETHYLENE DIAMINE, ETHYLENE GLYCOL, ETHYLENIMINE, FULMINATES, HYDROFLUORIC ACID, IODINE HEPTAFLUORIDE, INDANE AND NITRIC ACID, IRON, ISOPRENE, LITHIUM SILICIDE, MERCURIC NITRIDE, MESITYL OXIDE, METALS (POWDERED), NITRIC ACID AND GLYCERIDES, P-NITROTOLUENE, PENTASILVER TRIHYDROXYDIAMINOPHOSPHATE, PERCHLORATES, 
PER IHLORIC ACID, PERMANGANATES AND BENZENE, 1-PHENYL-2-METHYL-PROPYL ALCOHOL AND HYDROGEN PEROXIDE, PHOSPHORUS, PHOSPHORUS ISOCYANATE, PICRATES, POTASSIUM TERT-BUTOXIDE, POTASSIUM CHLORATE, POTASSIUM PERMANGANATE, POTASSIUM CHLORIDE, BETA-PROPIOLACTONE, PROPYLENE OXIDE, PYRIDINE, RUBIDIUM ACETYLENE CARBIDE, SILVER PERMANGANATE, SODIUM, SODIUM CARBONATE, SODIUM CHLORATE, SODIUM HYDROXIDE, STEEL, STYRENE MONOMER, TOLUENE AND NITRIC ACID, VINYL ACETATE, ZINC CHLORATE

Incompatible Materials Comments: NISS

Hazardous Polymerization: WILL NOT OCCUR

Combustion and Decomposition Products:

THERMAL DECOMPOSITION PRODUCTS INCLUDE HIGHLY TOXIC FUMES OF SULFUR OXIDES.

Combustion and Decomposition Products Comments:

NISS

6. HEALTH HAZARD DATA

OSHA Standards:

ACGIH TLV:

NIOSH Recommendation:

Immediately Dangerous to Life \& Health:

Other Exposure Limits:

Acute Inhalation:

Acute Swallowing:

Acute Skin Absorption:

Acute Skin Contact:

Acute Eye Contact:
TWA $1 \mathrm{MG} / \mathrm{CU} M$

TWA 1 MG/CU M, STEL 3 MG/CU M (1992-93)

10-HR TWA 1 MG/CU $M$

$80 \mathrm{MG} / \mathrm{CU} \mathrm{M}$

NISS

INHALATION OF MIST OR VAPOR CAUSES NOSE AND THROAT IRRITATION, COUGH, AND/OR CHEMICAL BURNS TO RESPIRATORY TRACT. DELAYED SYMPTOMS MAY INCLUDE PULMONARY EDEMA, TIGHTNESS IN CHEST, CYANOSIS, HYPOTENSION, BRONCHITIS, OR EMPHYSEMA.

INGESTION OF CONCENTRATED ACID CAUSES SEVERE CHEMICAL BURNS TO MOUTH, THROAT, AND ABDOMEN FOLLOWED BY VOMITING AND DIARRHEA OF DARK PRECIPITATED BLOOD. ASPHYXIA MAY DCCUR FROM SWELLING OF THE THROAT. PERFORATION OF THE ESOPHAGUS AND STOMACH MAY OCCUR. MAY HAVE ADVERSE EFFECT ON KIDNEY FUNCTION AND MAY BE FATAL.

\section{NISS}

SKIN CONTACT WITH CONCENTRATED ACID CAUSES SEVERE CHEMICAL BURNS.

DIRECT CONTACT WITH CONCENTRATED ACID CAUSES CHEMICAL BURNS WITH POSSIBLE SEVERE DAMAGE, OFTEN LEADING TO BLINDNESS. DILUTE SOLUTIONS PRODUCE MORE TRANSIENT EFFECTS FROM WHICH 
Chronic Effects:

Target Organs/Systems:

Inhalation Emergency:

Swallowing Emergency:

Skin Contact Emergency:

Eye Contact Emergency:

Physicians Notes:

Aggravated Conditions :

Carcinogenicity:
RECOVERY MAY BE COMPLETE.

PROLONGED OR REPEATED INHALATION OF MIST OR VAPOR MAY CUASE BRONCHITIS, IMPAIRMENT OF LUNG FUNCTION AND PERMANENT LUNG DAMAGE WITH EPITHELIAL HYPERPLASIA AND THICKENING OF THE BRONCHIOLAR WALLS. INHALATION OF MIST MAY ALSO PRODUCE ETCHING OF THE DENTAL ENAMEL FOLLOWED BY EROSION OF THE ENAMEL WITH LOSS OF TOOTH SUBSTANCE.

NISS

REMOVE TO FRESH AIR AND GIVE ARTIFICIAL RESPIRATION IF NOT BREATHING. GET MEDICAL AID.

DO NOT INDUCE VOMITING. DILUTE STOMACH CONTENT WITH LARGE AMOUNT OF WATER OR MILK. GET MEDICAL AID.

REMOVE CONTAMINATED CLOTHING AND RINSE SKIN WITH RUNNING WATER FOR AT LEAST 15 MINUTES. GET MEDICAL AID.

FLUSH EYES AT ONCE WITH WATER FOR AT LEAST 15 MINUTES. GET MEDICAL AID.

NISS

NISS

SUFFICIENT EVIDENCE FOR CARCINOGENICITY IN HUMANS. (IARC 1992)

The MMES Carcinogen Control Program includes human, human suspect, and confirmed animal carcinogens. [See MMES Carcinogen: (Yes/No or Not Yet Determined) in Section 1.] Chemicals and compounds in concentration of 0.18 or greater are subject to the guidelines set forth in the MMES carcinogen Control program. Substitution with a non-carcinogen should be made if feasible.

Genotoxicity: NISS

Reproductive/Developmental Toxicity: NISS

This section reflects materials listed in the Registry of Toxic Effects of Chemical Substances that have positive reproductive effects data for at least one mammalian species. Such effects may include paternal, maternal, fertility, embryo/fetus, neonatal, developmental abnormalities or tumorigenesis. An entry does not automatically imply that the substance is hazardous for common use. A hazard determination is generally required.

\section{...... 7. SPILL LEAK AND DISPOSAL INFORMATION}

Spill or Leak Emergency:

SUMMON HELP IMMEDIATELY.

$Y-12$ : SHIFT SUPERINTENDENT, 4-7172 OR 911 
$X-10:$ SHIFT SUPERVISOR, 4-6606 OR 911

K-25: SHIFT SUPERVISOR, 4-3282 OR 911

PADUCAH: SHIFT SUPERVISOR, BELL-6211, PAX-511

MINIMIZE THE SPILL OR RELEASE IF YOU CAN DO SO SAFELY.

EVACUATE THE AREA.

Disposal procedure:

Y-12: TRANSFER STORAGE OR DISPOSAL OF WASTE PROCEDURE 70-903, DISPOSAL OF HAZARDOUS MATERIALS. FOR MORE INFORMATION, CONTACT THE WASTE DISPOSAL DEPARTMENT, 6-7768.

X-10: WASTE, TRANSPORTATION, STORAGE, AND DISPOSAL MANUAL, EPM-8.0, FORM UCN-13696. FOR MORE INFORMATION, CONTACT THE DEPARTMENT OF ENVIRONMENTAL MANAGEMENT, 4-7467.

K-25: SPP-4600, FORM UCN-12463. FOR MORE INFORMATION, CONTACT THE WASTE MANAGEMENT DIVISION, 4-8214.

PADUCAH: ESH-28, FORM UCN-12463A. FOR MORE INFORMATION, CONTACT THE WASTE MANAGEMENT DEPARTMENT, PAX-401 OR BELL-6319.

...... 8. SPECIAL PROTECTION INFORMATION ......

Respirators:

RESPIRATORS MAY BE REQUIRED WHEN USING THIS MATERIAL. CONTACT THE INDUSTRIAL HYGIENE DEPARTMENT FOR MORE INFORMATION.

Ventilation:

CONDITIONS, QUANTITIES, AND OTHER FACTORS DETERMINE VENTILATION REQUIREMENTS. IF THERE ARE UNCERTAINTIES, CONTACT THE INDUSTRIAL HYGIENE DEPARTMENT.

Gloves :

WEAR CHEMICAL-RESISTANT GLOVES. CONSULT MANUFACTURER FOR SPECIFIC TYPE OF GLOVE FOR PROTECTION AGAINST THIS SUBSTANCE.

Eye Protection:

WEAR FACESHIELD ( 8 INCH MINIMUM) AND/OR VENTED SAFETY GOGGLES.

Other Protective Equipment: DO NOT GET IN EYES, ON SKIN, ON CLOTHING. DO NOT BREATHE VAPOR OR MIST. DO NOT ADD WATER TO ACID. WEAR RUBBER SUIT, RUBBER BOOTS, AND HARD HAT. DO NOT SMOKE IN AREA OF USE OR IN STORAGE AREA.

Impurities, By-Products, Contaminants: NISS

...... 9. SPECIAL HANDLING, STORING, PACKAGING $\ldots \ldots$

PROTECT AGAINST PHYSICAL DAMAGE AND WATER. SEPARATE FROM COMBUSTIBLE MATERIAL. PREVENT HYDROGEN GAS BUILD-UP. SMOKING, FLAMES, AND SPARKS SHOULD NOT BE PERMITTED IN STORAGE AREA. DO NOT ALLOW WATER TO ENTER STORAGE CONTAINERS AS A VIOLENT REACTION CAN OCCUR. WHEN DILUTING WITH WATER, ADD ACID TO WATER, NEVER ADD WATER TO ACID.

10. TRANSPORTATION DATA $\ldots \ldots$

DOT Information:

(Name, Class, Label, Number) 
1) HYDROGEN SULFATE CORROSIVE MATERIAL CORROSIVE

UN1830

2) NORDHAUSEN ACID CORROSIVE MATERIAL CORROSIVE UN1832

3) OIL OF VITRIOL CORROSIVE MATERIAL CORROSIVE

UN1832

4) SPENT SULFURIC ACID CORROSIVE MATERIAL CORROSIVE UN1832

5) SULFURIC ACID, SPENT CORROSIVE MATERIAL CORROSIVE UN1832

Reportable Quantity: References :
1000 LB (454 KG)

- NATIONAL FIRE PROTECTION ASSOCIATION. FIRE PROTECTION GUIDE ON HAZARDOUS MATERIALS. 7TH ED. BOSTON, MA: NATIONAL FIRE PROTECTION ASSOCIATION, 1978.

- CHEMLINE, CHEMICAL DICTIONARY ONLINE (DATA BASE), NATIONAL LIBRARY OF MEDICINE, BETHESDA MD.

- RTECS, REGISTRY OF TOXIC EFFECTS OF CHEMICAL SUBSTANCES (DATABASE). NATIONAL LIBRARY OF MEDICINE, BETHESDA MD.

- THE MERCK INDEX. 10TH ED. RAHWAY NJ, 1983.

- HAWLEY, G.G. THE CONDENSED CHEMICAL DICTIONARY. 1OTH ED. NEW YORK: VAN NOSTRAND REINHOLD CO., 1981 .

- GOSSELIN, R.E., R.P. SMITH, AND H.C. HODGE. CLINICAL TOXICOLOGY OF COMMERCIAL PRODUCTS. 5TH ED. WILLIAMS AND WILKINS, BALTIMORE MD, 1984.

- WEAST, R.C. (ED.). HANDBOOK OF CHEMISTRY AND PHYSICS, 67TH ED., BOCA RATON, FL: CRC PRESS INC. , 1986-1987.

- CHRIS - HAZARDOUS CHEMICAL DATA. MANUAL TWO. U.S. COAST GUARD, DEPARTMENT OF TRANSPORTATION U.S. GOVERNMENT PRINTING OFFICE, WASHINGTON DC, JUNE 1985 .

- AMERICAN CONFERENCE OF GOVERNMENTAL INDUSTRIAL HYGIENISTS. TLV'S THRESHOLD LIMIT VALUES AND BIOLOGICAL EXPOSURE INDICES. CINCINNATI OH: AMERICAN CONFERENCE OF GOVERNMENTAL HYGIENISTS

- THE MERCK INDEX. 11TH ED. RAHWAY NJ, 1989.

- MATERIAL SAFETY DATA SHEETS (MSDS) PROVIDED BY 
MANUFACTURERS.

- HSDB, HAZARDOUS SUBSTANCES DATA BANK (DATA BASE), NATIONAL LIBRARY OF MEDICINE, BETHESDA MD, 1990.

- SCIENTIFIC REVIEW COMMITTEE FOR MSDS

WARNING: THE INFORMATION CONTAINED HEREON IS INTENDED SOLELY FOR THE USE OF EMPLOYEES OF MARTIN MARIETTA ENERGY SYSTEMS, INC.

THE INFORMATION IS NOT INTENDED TO BE A DEFINITIVE STATEMENT

OF ALL HAZARDS ASSOCIATED WITH SAID MATERIAL OR ALL METHODS

OF COUNTERACTING HUMAN EXPOSURE TO SAME. USERS ARE CAUTIONED

TO PROCEED WITH DUE CARE IN THE HANDLING, STORING AND

DISPOSAL OF THIS MATERIAL AND TO SEEK FURTHER INFORMATION

REGARDING PARTICULAR APPLICATIONS AS REQUIRED.

MARTIN MARIETTA ENERGY SYSTEMS, INC.

P.O. BOX 2008

BLDG. 3550, MS 6291

OAK RIDGE, TENNESSEE 37831

PHONE: 615-574-0784

FAX : $615-576-6087$ 
Martin Marietta Energy Systems, Inc.

Material Safety Data Sheet

RECID :

CAS NO:

Material Name:

Synonyms :

Status Information:

Modification History:

Special Condition:

HM Group Code :

MMES Carcinogen:

RTECS Reproductive/

Developmental Effector:

AVID No:

\section{-.... 1. IDENTIFICATION -.....}

00275

007697-37-2

Version No: 5

NITRIC ACID

Version Date: 11/02/1992

1) AQUA FORTIS

2) AZOTIC ACID

3) EM SCIENCE CATALOG NUMBERS: NX0409, NX0409I, NX0411，NX0412，441

4) EM SCIENCE CATALOG NUMBERS: NX0409P, NX0409T, NX0409TP

5) FISHER SCIENTIFIC CHEMICAL DIVISION CAT NUMBERS: A200500, A202500

6) FUMING HYDROGEN NITRATE

7) HYDROGEN NITRATE

8) JT BAKER PRODUCT CODES: 4801,9606,9597,5113,9601, $9602,5371,9598,9605,9600,9616$

9) JT BAKER PRODUCT CODES: 9624,5600,6901

10) LEEMAN LABS CATALOG NUMBER: 602-00003

11) LEEMAN LAABS MORE THAN $70 \%$ NITRIC ACID

12) NITRIC ACID $70 \%$ AR IN GLASS BOTTLE

13) NITRIC ACID, FUMING

14) NITRIC ACID, RED FUMING

15) NITROUS FUMES

16) NITRYL HYDROXIDE

17) RFNA

18) SIGMA-ALDRICH PRODUCT NUMBER: Z5523

\begin{tabular}{cccc} 
MSDS & MSDS & MSDS & $\begin{array}{c}\text { Request } \\
\text { Type }\end{array}$ \\
\hline Status & Available & Outstanding \\
\hline$D$ & A & Yes & No
\end{tabular}

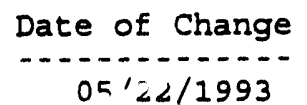

Last Modifier

Date of Entry $10 / 30 / 1992$

N

C

No or Not Yet Determined
LBC9624-5

LBCEM 4 4 1-2 LBCMF JT $9501-33$

LBCMJRT9589-33

LBCEP6739A-1

LBC 9598-33

LBCMR JT9598-33

LBSJT6901-5

LBC5639-02

LBCH44500-4

LBC6901-05 


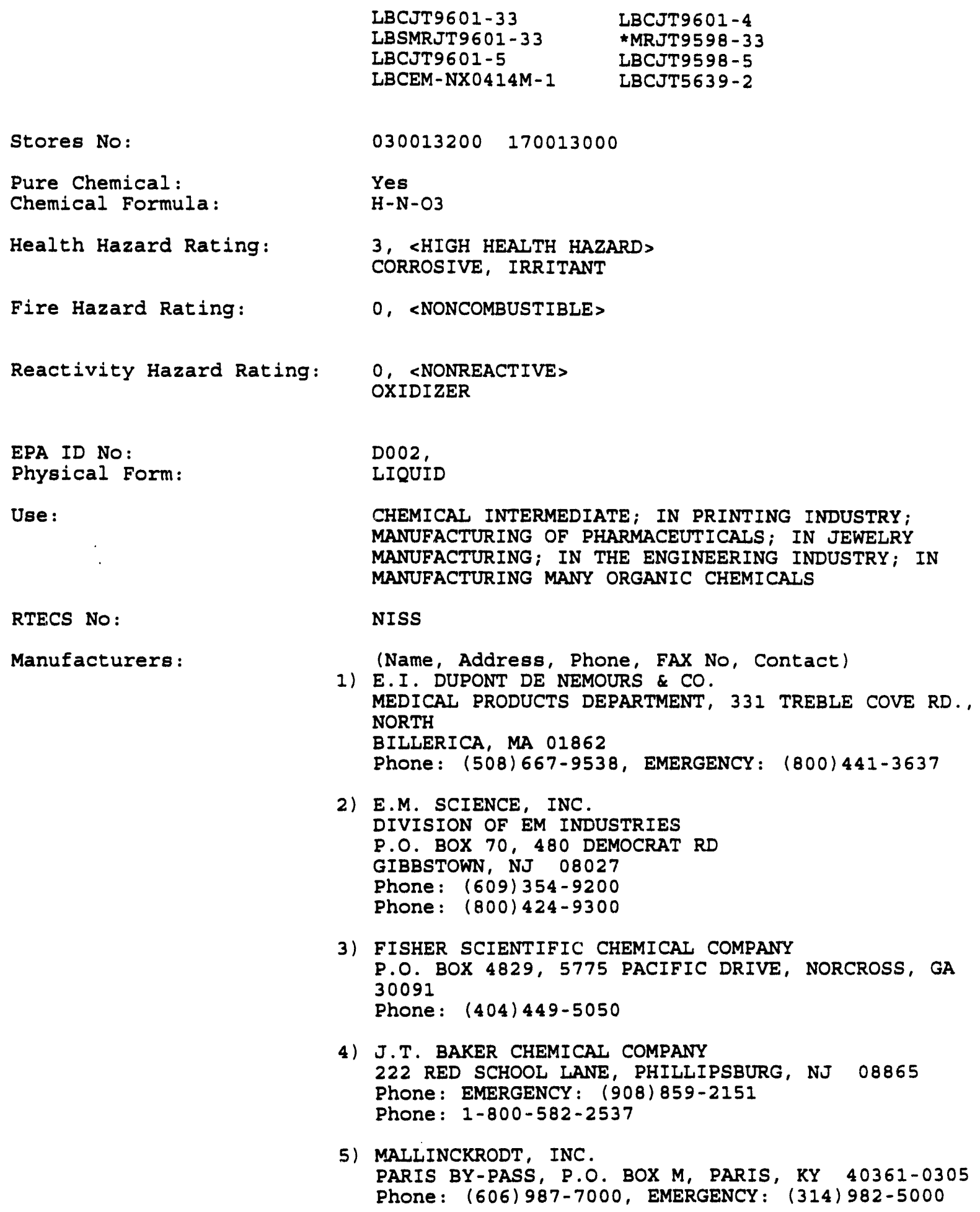

1) E.I. DUPONT DE NEMOURS \& CO. MEDICAL PRODUCTS DEPARTMENT, 331 TREBLE COVE RD., NORTH

2) E.M. SCIENCE, INC.

DIVISION OF EM INDUSTRIES

P.O. BOX 70, 480 DEMOCRAT RD

GIBBSTOWN, NJ 08027

Phone: (609) 354-9200

Phone: (800)424-9300

3) FISHER SCIENTIFIC CHEMICAL COMPANY P.O. BOX 4829,5775 PACIFIC DRIVE, NORCROSS, GA 30091

Phone: (404)449-5050

4) J.T. BAKER CHEMICAL COMPANY

222 RED SCHOOL LANE, PHILLIPSBURG, NJ 08865

Phone: EMERGENCY: (908) 859-2151

Phone: 1-800-582-2537

5) MALLINCKRODT, INC.

PARIS BY-PASS, P.O. BOX M, PARIS, KY 40361-0305 Phone: (606)987-7000, EMERGENCY: (314)982-5000 
MSDS Listing:

\begin{tabular}{ll} 
MFR No & Manufacturer Name \\
\hline DUPON3 & E.I. DUPONT DE NEMOURS \& CO. \\
EMS & E.M. SCIENCE, INC. \\
FSCO & FISHER SCIENTIFIC CHEMICAL COMPANY \\
JTB & J.T. BAKER CHEMICAI COMPANY \\
MKDT & MALIINCKRODT, INC.
\end{tabular}

\begin{tabular}{lcc} 
MFR MSDS & MSDS & Used \\
To Modify \\
Prep Date & Rcvd Date & Tech Data \\
\hline $09 / 01 / 1990$ & $03 / 19 / 1992$ & Yes \\
$11 / 26 / 1991$ & $03 / 12 / 1993$ & No \\
$04 / 23 / 1990$ & $03 / 19 / 1992$ & Yes \\
$08 / 09 / 1991$ & $03 / 19 / 1992$ & Yes \\
$10 / 21 / 1986$ & $03 / 19 / 1992$ & Yes
\end{tabular}

...... 2. PHYSICAL DATA $\ldots . . .$.

Material Description:

Molecular Weight:

Density/Specific Gravity:

Vapor Density:

Vapor Pressure:

Boiling Point :

Melting Point:

Freezing point :

Percent Volatiles:

Solubility in Water: Evaporation Rate:
COLORLESS OR YELLOW TO BROWNISH LIQUID, FUMES IN AIR. COMMERCIAL NITRIC ACID CONTAINS 68\% AND $50 \%$ NITRIC ACID IN WATER. RED FUMING NITRIC ACID CONTAINS NOT LESS THAN $85 \%$ NITRIC ACID AND LESS THAN $5 \%$ WATER.

63.01

1.50 (WATER=1)

$2.2(\mathrm{AIR}=1)$

47.8 MM HG

181 DEG F, 83 DEG C

-44 DEG F, -42 DEG C

NISS

1008

MISCIBLE

NISS

Name :

RECID :

Percent Comments:

RTECS Reprod Effector: No or Not Yet Determined

MMES Carcinogen:

Hazard Evaluation:

- 3. INGREDIENTS -.....

CAS NO: PURE CHEMICAL

CAS NO: RTECS NO:

4. FIRE AND EXPLOSION HAZARD DATA $\ldots . . . .$.

Flash Point:

NONFLAMMABLE

Autoignition:

NONFLAMMABLE

Lower Flammability Limit:

NONFLAMMABLE

Upper Flammability Limit:

NONFLAMMABLE

Extinguishing Media:

WATER SPRAY/FOG

DRY CHEMICAL

SODA ASH

USE WATER TO DISPERSE VAPORS. 
Firefighting Procedures:

Fire and Explosion Hazards:
OR USE EXTINGUISHING MEDIA SUITABLE FOR SURROUNDING MATERIAI.

COOL CONTAINERS EXPOSED TO HEAT OR FLAMES WITH WATER FROM THE SIDES UNTIL WELL AFTER THE FIRE HAS BEEN EXTINGUISHED.

REMOVE CONTAINERS FROM FIRE AREA IF POSSIBLE. VERY CORROSIVE, MUST BE KEPT OFF SKIN. WEAR PRESSURE-DEMAND， SELF-CONTAINED BREATHING APPARATUS AND CHEMICAL PROTECTIVE SUIT. USE WATER TO DISPERSE VAPORS

MAY IGNITE WHEN HEATED WITH ORGANIC MATERIAL. TOXIC GASES AND FUMES ARE EMITTED UNDER FIRE CONDITIONS.

CAN REACT EXPLOSIVELY WITH SOME REDUCING AGENTS AND COMBUSTIBLES: METAI POWDERS, CARBIDES, HYDROGEN SULFIDE, TURPENTINE. RED FUMING NITRIC ACID IS A DANGEROUS FIRE HAZARD AND POWERFUL OXIDIZING AGENT.

HAZARDOUS

DECOMPOSITION PRODUCTS: NITROGEN DIOXIDE, NITRIC OXIDE, AND NITRIC ACID FUMES.
Stability:

Shelf Life In Days:

Shelf Life Comments:

Conditions to Avoid:
5. REACTIVITY DATA

STABLE

AVOID HEAT. AVOID EXPOSURE TO MOISTURE. $100 \%$ NITRIC ACID CANNOT BE STORED IN THE PRESENCE OF LIGHT WITHOUT FORMATION OF NITRIC OXIDE WHICH CAUSES DISCOLORATION.

Incompatible Materials:

ACETONITRILE, CESIUM CARBIDE, CUPRIC NITRIDE, CYANIDES, 1,2-DIAMINOETHANE BISTRIMETHYL' GOLD, DINITROTOLUENE, EPICHLOROHYDRIN, 5-ETHYL-2-METHYL PYRIDINE, CYCLOPENTADIENE

BENZENE, TOLUENE, METALS, METAL CARBIDES, 4-METHYLCYCLOHEXANONE, NITROBENZENE AND WATER, NITROMETHANE, POLYDIBROMO-SILANES, PHOSPHORUS TRICHLORIDE, POTASSIUM HYPOPHOSPHITE (ON EVAPORATION), RUBIDIUM CARBIDE, SELENIUM IODOPHOSPHIDE, SULFUR DIOXIDES, THIOCYANATES, THIOCYANIC ACID, METAL SALTS, THIOPHENES, TETRABORANE, TRICADMIUM DIPHOSPHIDE, TRITHIOACETONE, ACETONE, ACETIC ACID, SULFURIC ACID, GLYCERIDES, TRIAZINE, TRIFLUORACETIC ANHYDRIDE, I.AMINO THIOAZOLE, CYANATES, FLUORINE, LACTIC ACID, HYDROGEN FLUORIDE, MESITYLENE, PERCHLORATES, PHTHALIC ACID, PHTHALIC ANHYDRIDE, REDUCING AGENTS, TITANIUM ALLOY, ACRYLONITRILE, ALCOHOLS, ARSINE, PHOSPHINE, DIPHENYLDISTIBENE, CARBON, CHLORINE TRIFLUORIDE, TEREPHTHALIC ACID, THIOALDEHYDES, THIOKETONES, URANIUM, URANIUM ALLOYS, SULFAMIC ACID, BUTANETHIOL, CROTONALDEHYDE, TETRAPHOSPHORUS, ANTIMONY, ANION EXCHANGE RESIN, ACROLEIN, ALLYL ALCOHOL, ALLYL CHLORIDE, 2-AMINOETHANOL, AMMONIUM HYDROXIDE, BISMUTH, N-BUTYRALDEHYDE, CHLOROSULFONIC ACID, CRESOL, CUMENE, DIISOPROPYL ETHER, ETHYLENEDIAMINE, POLYALKENES, GLYOXAL, ISOPRENE, MESITYL OXIDE, 2-METHYL-5-ETHYLPYRIDINE, OLEUM, PROPYLENE OXIDE, PROPIOLACTONE (BETA-), PYRIDENE, SODIUM HYDROXIDE, VINYL ACETATE, VINYLDENE CHLORIDE, DE, DIETHYLETHER, HYDRAZOIC ACTD, P-XYLENE IN THE PRESENCE OF SULFURIC ACID 


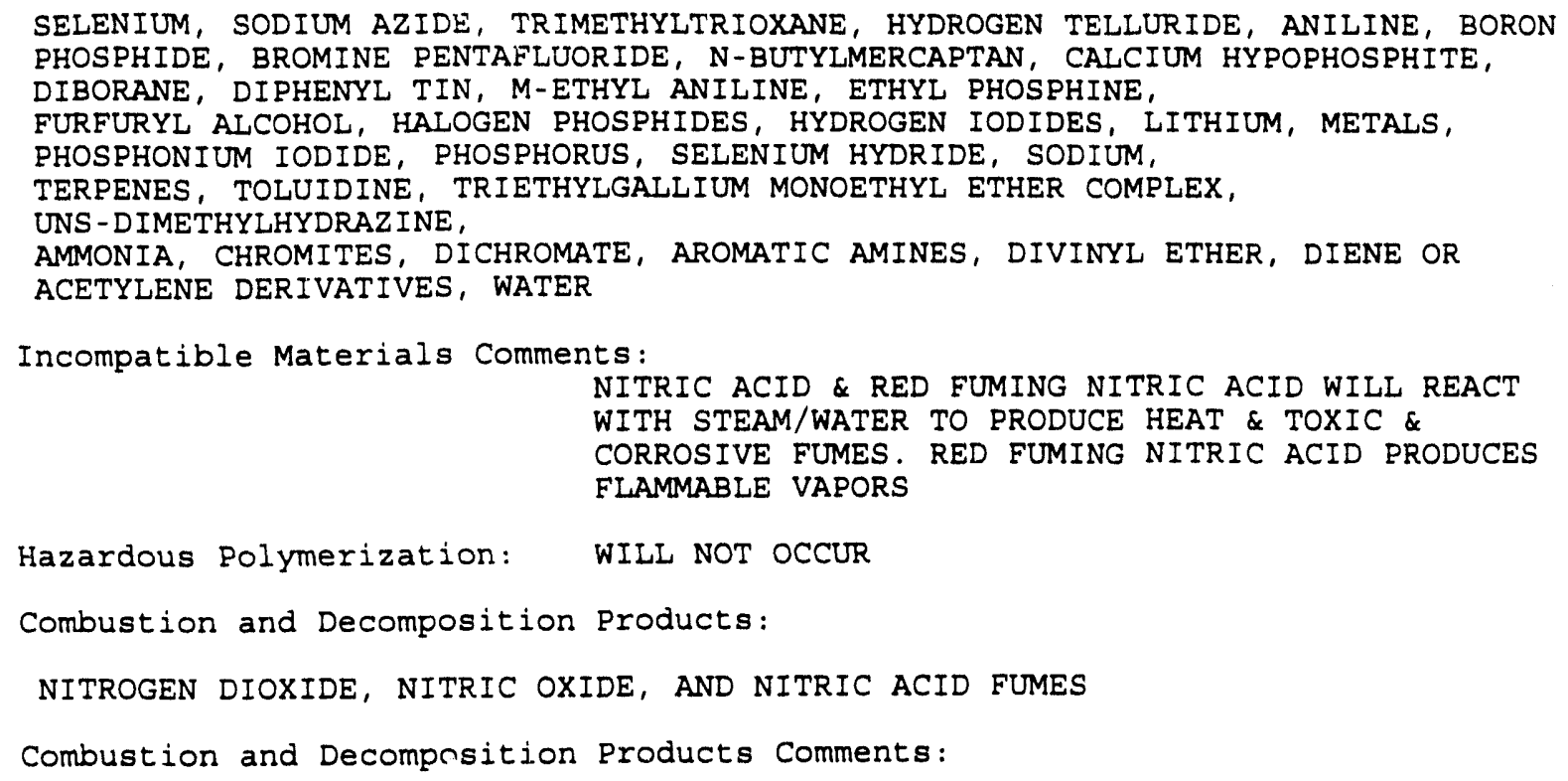

OSHA Standards:

ACGIH TLV :

NIOSH Recommendation:

Immediately Dangerous to Life \& Health:

Other Exposure Limits:

Acute Inhalation:

Acute Swallowing:

Acute Skin Absorption:

Acute Skin Contact:
TWA 2 PPM OR 5 MG/CU M, STEL 4 PPM OR 10 MG/CU M FOR NITRIC ACID

TWA 2 PPM OR 5 MG/CU M, STEL 4 PPM OR 10 MG/CU M FOR NITRIC ACID (1991-92)

10-HR TWA 2 PPM OR 5 MG/CU M FOR NITRIC ACID

100 PPM

NISS

SEVERE NOSE \& THROAT IRRITATION WITH DELAYED FEVER, CYANOSIS \& PULMONARY EDEMA, COUGH, BREATHING DIFFICULTY, BRONCHOPNEUMONIA.

SEVERELY TOXIC, CAUSES CHEMICAL BURNS \& CORROSION OF MOUTH, ESOPHAGUS, STOMACH \& SMALL INTESTINES, NAUSEA, VOMITING, ABDOMINAL PAIN, DIARRHEA, KIDNEY DAMAGE, CIRCULATORY COLLAPSE, DEATH.

WIDESPREAD OR PROLONGED CONTACT WITH NITRIC ACID MAY RESULT IN THE ABSORPTION OF HARMFUL AMOUNTS OF MATERIAIS

NITRIC ACID PRODUCES IMMEDIATE CHEMICAL BURNS. CONCENTRATED AQUEOUS SOLITIONS CAUSE EARLY SENSATION OF PAIN, PAINFUL ULCERS. LIQUID IS MILDLY IRRITATING TO THE SKIN. 
Acute Eye Contact:

Chronic Effects:

Target Organs/systems:

Inhalation Emergency:

Swallowing Emergency:

Skin Contact Emergency:

Eye Contact Emergency:

Physicians Notes:

Aggravated Conditions:
IIQUID OR VAPOR CAUSES SEVERE EYE IRRITATION, DEEP-SEATED CHEMICAL BURNS IF NOT REMOVED AT ONCE. PERMANENT VISUAL DEFECTS OR BLINDNESS MAY RESULT.

CHRONIC BRONCHITIS, CHEMICAL PNEUMONITIS DUE TO VAPORS

RESPIRATORY SYSTEM，KIDNEYS

REMOVE TO FRESH AIR AND GIVE ARTIFICIAL RESPIRATION IF NOT BREATHING. GET MEDICAL AID.

DO NOT INDUCE VOMITING. DILUTE STOMACH CONTENT WITH LARGE AMOUNT OF WATER OR MILK. GET MEDICAL AID.

REMOVE CONTAMINATED CLOTHING AND RINSE SKIN WITH RUNNING WATER FOR AT LEAST 15 MINUTES. GET MEDICAL AID.

FLUSH EYES AT ONCE WITH WATER FOR AT LEAST 15 MINUTES. GET MEDICAL AID.

FOR INHALATION MONITOR PATIENT FOR RESPIRATORY DISTRESS, CHECK FOR CHEMICAL BURNS.

DAMAGED SKIN, EYE DISORDERS, CARDIOPULMONARY DISEASE

NISS

Carcinogenicity:

The MMES Carcinogen Control Program includes human, human suspect, and confirmed animal carcinogens. [See MMES Carcinogen: (Yes/No or Not Yet Determined) in section 1.] Chemicals and compounds in concentration of $0.1 \%$ or greater are subject to the guidelines set forth in the MMES Carcinogen Control program. Substitution with a non-carcinogen should be made if feasible.

Genotoxicity:

NISS

Reproductive/Developmental Toxicity: NISS

This section reflects materials listed in the Registry of Toxic Effects of Chemical Substances that have positive reproductive effects data for at least one mammalian species. Such effects may include paternal, maternal, fertility, embryo/fetus, neonatal, developmental abnormalities or tumorigenesis. An entry does not automatically imply that the substance is hazardous for common use. A hazard determination is generally required.

Spill or Leak Emergency:

SUMMON HELP IMMEDIATELY.

Y-12: SHIFT SUPERINTENDENT, 4-7172 OR 911

X-10: SHIFT SUPERVISOR, 4-6606 OR 911 
K-25: SHIFT SUPERVISOR, 4-3282 OR 911

PADUCAH: SHIFT SUPERVISOR, BELL-6211, PAX-511

MINIMIZE THE SPILL OR RELEASE IF YOU CAN DO SO SAFELY.

EVACUATE THE AREA.

Disposal Procedure:

Y-12: TRANSFER STORAGE OR DISPOSAL OF WASTE PROCEDURE 70-903, DISPOSAL OF HAZARDOUS MATERIALS. FOR MORE INFORMATION, CONTACT THE WASTE DISPOSAL DEPARTMENT, 6-7768.

X-10: WASTE, TRANSPORTATION, STORAGE, AND DISPOSAL MANUAL, EPM-8.0, FORM UCN-13696. FOR MORE INFORMATION, CONTACT THE DEPARTMENT OF ENVIRONMENTAL MANAGEMENT, 4-7467.

K-25: SPP-4600, FORM UCN-12463. FOR MORE INFORMATION, CONTACT THE WASTE MANAGEMENT DIVISION, $4-8214$.

PADUCAH: ESH-28, FORM UCN-12463A. FOR MORE INFORMATION, CONTACT THE WASTE MANAGEMENT DEPARTMENT, PAX-401 OR BELL-6319.

..... 8. SPECIAL PROTECTION INFORMATION -.....

Respirators:

RESPIRATORS MAY BE REQUIRED WHEN USING THIS MATERIAL. CONTACT THE INDUSTRIAL HYGIENE DEPARTMENT FOR MORE INFORMATION .

Ventilation:

CONDITIONS, QUANTITIES, AND OTHER FACTORS DETERMINE VENTILATION REQUIREMENTS. IF THERE ARE UNCERTAINTIES, CONTACT THE INDUSTRIAL HYGIENE DEPARTMENT.

Gloves :

Eye Protection:

Other Protective Equipment:

Impurities, By-Products,

Contaminants: NISS
EMPLOYEE MUST WEAR APPROPRIATE PROTECTIVE GLOVES TO PREVENT ANY POSSIBILITY OF CONTACT WITH THIS CHEMICAL. PREFERRED MATERIALS: VITO N OR SARANEX.

EMPLOYEE MUST WEAR SPLASH-PROOF SAFETY GOGGLES AND A FACESHIELD TO PREVENT ANY POSSIBILITY OF CONTACT WITH THIS CHEMICAL. DO NOT WEAR CONTACT LENSES WHEN WORKING WITH CHEMICALS.

EMPLOYEE MUST WEAR APPROPRIATE PROTECTIVE (CHEMICAL-RESISTANT) CLOTHING AND EQUIPMENT TO PREVENT REPEATED OR PROLONGED SKIN CONTACT WITH THIS CHEMICAL. WHERE THERE IS ANY POSSIBILITY THAT AN EMPLOYEE'S EYES MAY BE EXPOSED TO THIS CHEMICAL, THE EMPLOYER SHALL PROVIDE AN EYE-WASH FOUNTAIN WITHIN THE IMMEDIATE WORK AREA FOR EMERGENCY USE.

-...... 9. SPECIAL HANDLING, STORING, PACKAGING $\ldots \ldots \ldots$

STORE IN STAINLESS STEEL, ALUMINUM OR GLASS CONTAINERS. DO NOT STORE NITRIC ACID THAT CONTAINS FLUORINATED COMPOUNDS IN GLASS. KEEP CONTAINER TIGHTLY CLOSED. STORE SEPARATELY AND AWAY FROM FLAMMABLE AND COMBUSTIBLE MATERIALS. 
10. TRANSPORTATION DATA

DOT Information:

(Name, Class, Label, Number)

1) NITRIC ACID

CORROSIVE MATERIAL

CORROSIVE

UN2031

2) NITRIC ACID, RED FUMING

CORROSIVE MATERIAL

CORROSIVE, OXIDIZER, POISON

UN2032

Reportable Quantity:

1000 LB (454 KG)

References :

- CHEMLINE, CHEMICAL DICTIONARY ONLINE (DATA BASE), NATIONAL LIBRARY OF MEDICINE, BETHESDA MD.

- RTECS, REGISTRY OF TOXIC EFFECTS OF CHEMICAL SUBSTANCES (DATABASE). NATIONAL LIBRARY OF MEDICINE, BETHESDA MD.

- THE MERCK INDEX. 1OTH ED. RAHWAY NJ, 1983.

- HAWLEY, G.G. THE CONDENSED CHEMICAL DICTIONARY. 1OTH ED. NEW YORK: VAN NOSTRAND REINHOLD CO., 1981 .

- SAX, N.I. DANGEROUS PROPERTIES OF INDUSTRIAL MATERIALS. 6THED. VAN NOSTRAND REINHOLD, NEW YORK NY, 1984.

- FIRE PROTECTION GUIDE ON HAZARDOUS MATERIALS, 9TH ED., NATIONAL FIRE PROTECTION ASSOCIATION, BOSTON MA, 1986.

- AMERICAN CONFERENCE OF GOVERNMENTAL INDUSTRIAL HYGIENISTS. TLV'S THRESHOLD LIMIT VALUES AND BIOLOGICAL EXPOSURE INDICES. CINCINNATI OH: AMERICAN CONFERENCE OF GOVERNMENTAL HYGIENISTS

- MATERIAL SAFETY DATA SHEETS (MSDS) PROVIDED BY MANUFACTURERS.

- hSDB, hazARDOUS substances data bank (DATA base), NATIONAL LIBRARY OF MEDICINE, BETHESDA MD, 1990.

- SCIENTIFIC REVIEW COMMITTEE FOR MSDS

WARNING: THE INFORMATION CONTAINED HEREON IS INTENDED SOLELY FOR THE USE OF EMPLOYEES OF MARTIN MARIETTA ENERGY SYSTEMS, INC.

THE INFORMATION IS NOT INTENDED TO BE A DEFINITIVE STATEMENT OF ALL HAZARDS ASSOCIATED WITH SAID MATERIAL OR ALL METHODS OF COUNTERACTING HUMAN EXPOSURE TO SAME. USERS ARE CAUTIONED TO PROCEED WITH DUE CARE IN THE HANDLING, STORING ANU DISPOSAI OF THIS MATERIAL AND TO SEEK FURTHER INFORMATION REGARDING PARTICUIAAR APPLICATIONS AS REQUIRED. MARTIN MARIETTA ENERGY SYSTEMS, INC.

P.O. BOX 2008

BLDG. 3550, MS 6291

OAK RIDGE, TENNESSEE 37831

PHONE: $615-574-0784$

FAX : 615-576-6087 


\section{DISTRIBUTION}

1. J. S. Abercrombie

2. E. R. Barham

3. H. L. Boston

4. C. Clark, Jr.

5. M. L. Conner

6. E. A. Ford

7-18. J. D. Marsh, Jr.

19-21. D. M. Matteo

22. J. S. McDonald

23. T. J. Newsom

24. P. T. Owen

25. A. W. Saulsbury

26. P. A. Schrandt

27. P. S. Wood

28-30. ORNL ER Document Management Center

31-33. Central ER Document Management Center

34. Laboratory Records Department

35. ORNL Patent Section

36. Central Research Library

37. R. C. Sleeman, DOE Oak Ridge Operations Office, P.O. Box 2001, Oak Ridge, TN 37831-8541

38. J. T. Sweeney, DOE Oak Ridge Operations Office, P.O. Box 2001, Oak Ridge, TN 37831-8541

39. Office of Assistant Manager for Energy Research and Development, DOE Oak Ridge Operations Office, P.O. Box 2001, Oak Ridge, TN 37831-8600

40-41. Office of Scientific and Technical Information, P.O. Box 62, Oak Ridge, TN 37831 

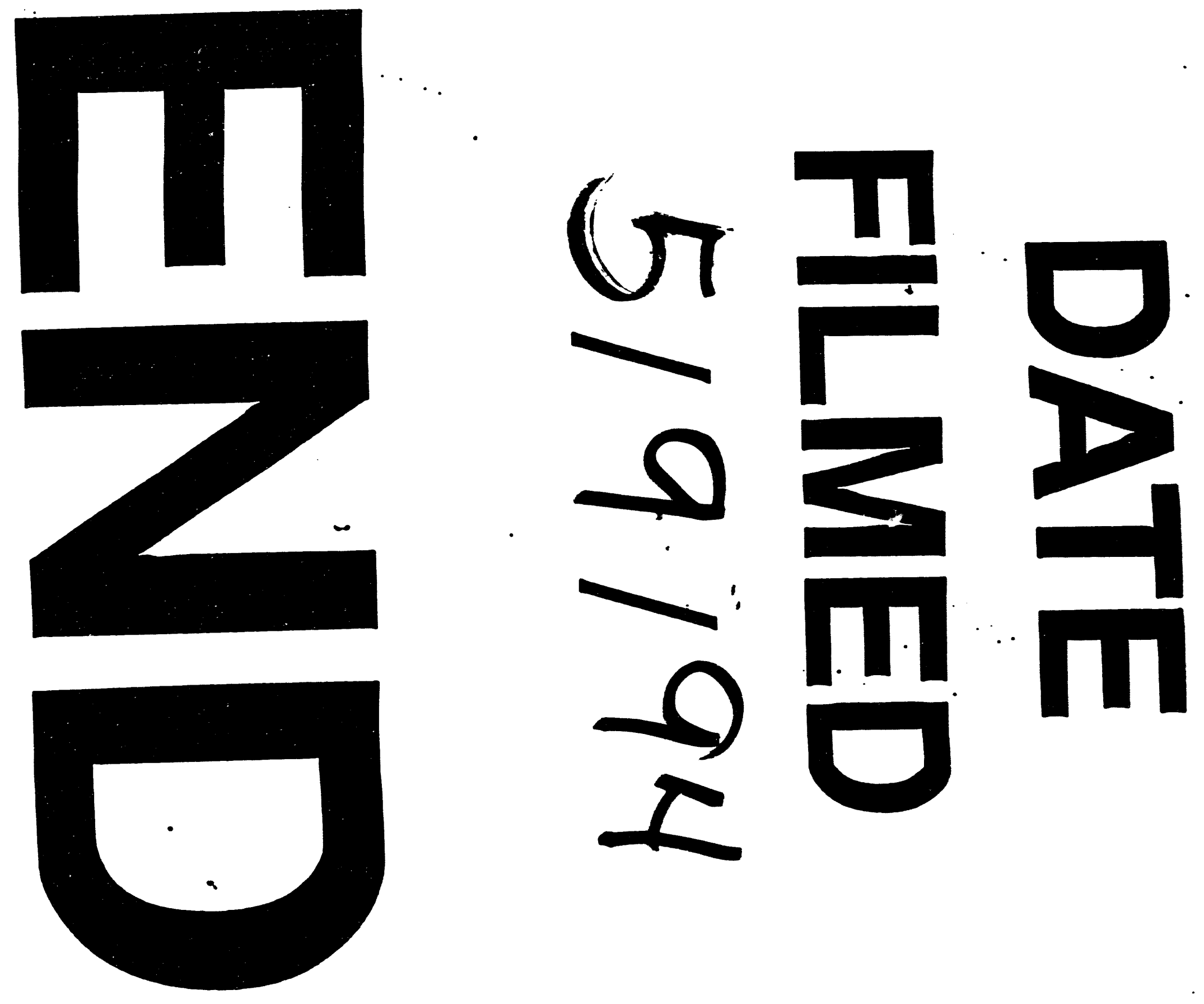


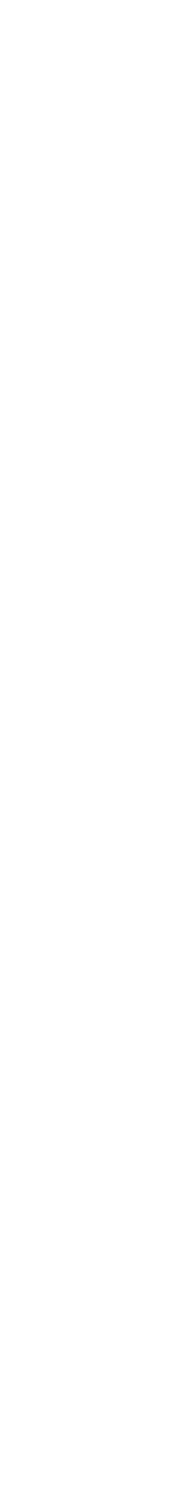

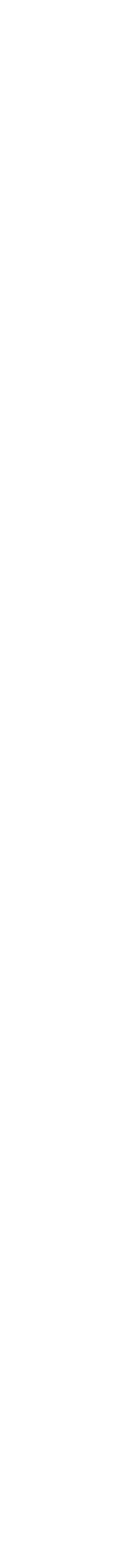

5

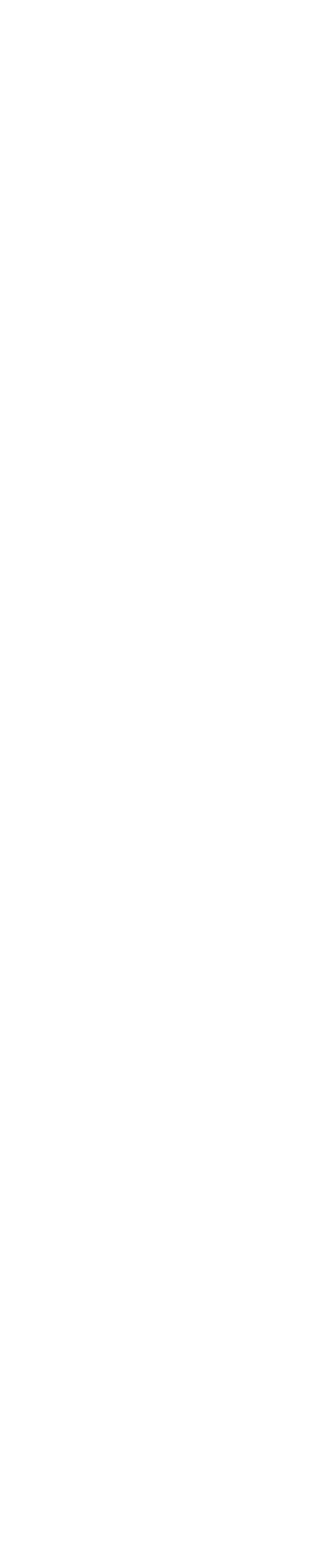

